Universidade de Brasília

Centro de Excelência em Turismo

\title{
Roteiros Turísticos de Aventura no DF e entorno
}

Nome do Aluno: Wlisses Fernando do Santos

Nome do Orientador: Rafael Sanzio Araújo do Santos

Monografia apresentada ao Centro de Excelência em Turismo da Universidade de Brasília como requisito parcial para a obtenção do certificado de Especialização para professores e pesquisadores em Turismo e Hospitalidade.

Brasília, DF, Fevereiro de 2004. 


\author{
Universidade de Brasília \\ Centro de Excelência em Turismo \\ Curso de Especialização para professores e pesquisadores em \\ Turismo e Hospitalidade
}

\title{
Roteiros Turísticos de Aventura no DF e entorno
}

AUTOR:

Wlisses Fernando do Santos

Matrícula: 03/00071

Parecer:

Esse trabalho foi julgado e aprovado para obtenção do grau de Estratégias Metodológicas para o Ensino e a Pesquisa, do curso de Especialização para professores e pesquisadores em Turismo e Hospitalidade da Universidade de Brasília - Unb.

Conceito:

Brasília, DF, Fevereiro de 2004. 
É proibida a duplicação ou reprodução desta Monografia, ou de parte da mesma, por quaisquer meios, sem autorização expressa do Autor.

Santos, Wlisses F.

Roteiros turísticos de aventura no DF e entorno / Wlisses Fernando do Santos. 88f.

Monografia do Curso de Especialização para Professores e Pesquisadores em Turismo e Hospitalidade Universidade de Brasília. Centro de Excelência em Turismo. Brasília, 2004.

Área de concentração: Turismo

Orientador: Rafael Sanzio Araújo do Santos.

1. Turismo

2. Turismo de Aventura

3. Roteiros Turísticos de Aventura no D.F e entorno. 
AUTOR: WLISSES FERNANDO DO SANTOS

Roteiros Turísticos de Aventura no DF e entorno

Comissão Avaliadora

Professor Orientador

Professor (a)

Professor (a)

Brasília, DF, Fevereiro de 2004. 
Agradecimentos

Agradeço a Deus por ter me iluminado durante toda a minha vida.

Aos meus pais e minha esposa, que sempre me incentivou a crescer em todos os sentidos e sem os quais jamais teria tido êxito.

Aos professores da Universidade de Brasília que, com ou sem dificuldades, sempre foram competentes e dispostos a passar o melhor do seu conhecimento.

Aos meus colegas, e mais que isso; amigos do curso, sempre companheiros em todas as horas. Desejo que todos obtenham o êxito profissional merecido.

Agradeço a todos aqueles que direta ou indiretamente contribuíram para a realização deste trabalho, quer através de críticas e sugestões, quer através do fornecimento de material de apoio ou de indicação de fontes indispensáveis de informação.

Em particular, agradeço ao meu orientador, pela ajuda prestada diante das dúvidas relativas ao trabalho. 
"Não pretendia competir e, na verdade, não concorro. Apenas me desvencilho de uma solução possível, que não foi procurada, mais surgiu, por assim dizer, já pronta... Brasília nasceu de um gesto primário de quem assina-la um lugar ou dele toma posse: dois eixos cruzando-se em ângulo reto, ou seja, o próprio sinal da cruz".

Lúcio Costa 


\section{Resumo}

O trabalho aborda o Turismo na Capital, visando adequar a oferta de produtos e serviços de turismo e hospitalidade com a demanda de visitantes à Brasília.

Para se fazer frente à necessidade de elaboração de roteiros de Turismo para o Cerrado de Brasília, o objetivo deste trabalho é elaborar roteiros de Turismo para a região, como também elaborar referencial teórico para pesquisas no assunto.

\section{Abstract}

The work approaches the Tourism in the Capital, aiming at to adjust it offers of products and services of tourism and hospitality with the demand of visitors to Brasilia. To become front to the necessity of elaboration of scripts of Tourism for the Open pasture of Brasilia, the objective of this work is to elaborate scripts of Tourism for the region, as also to elaborate referencial theoretician for research in the subject. 


\section{Sumário}

1. Roteiros turísticos de aventura no DF e entorno .......................................11

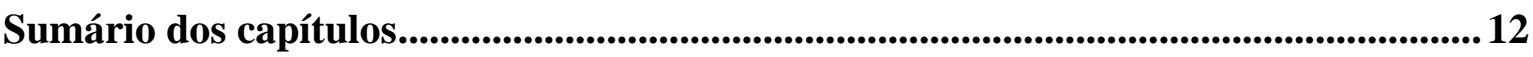

2. Evolução Histórica da Indústria do Turismo no mundo e no Brasil................ 13

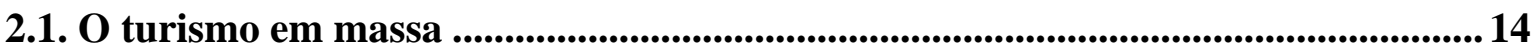

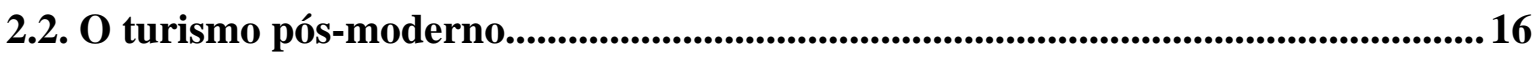

2.3. A Indústria do Turismo no Brasil ............................................................................ 17

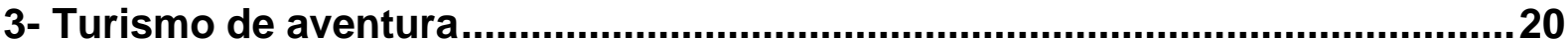

3.1- Como surgiu o termo turismo de aventura? ....................................................................... 23

3.2- Crescimento do Turismo de Aventura no Brasil ........................................................... 26

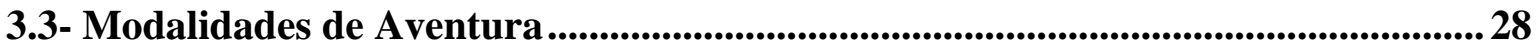

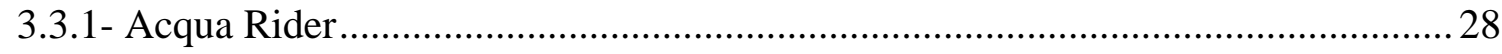

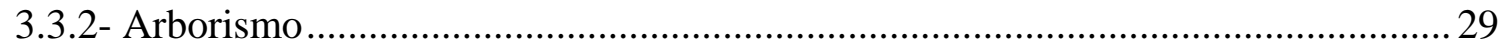

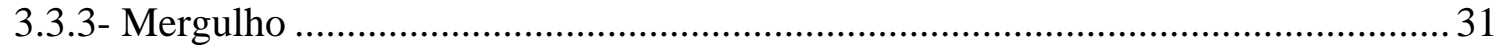

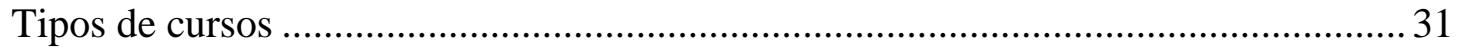

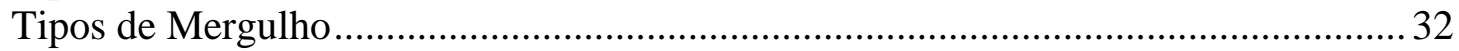

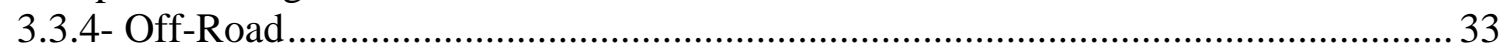

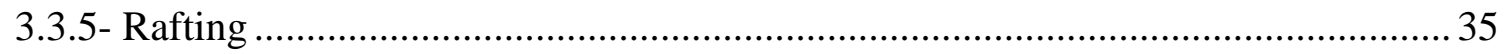

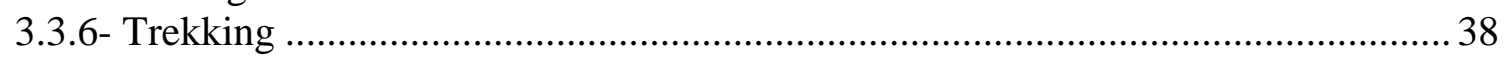

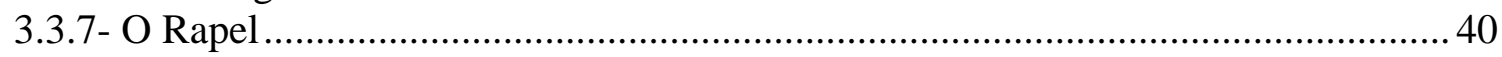

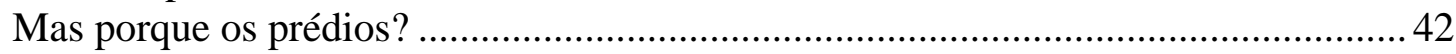

4. Turismo de Aventura no DF e entorno - Potencialidades...............................43

4.1- Formosa ........................................................................................................................................... 43

4.2- Cristalina .............................................................................................................................................. 44

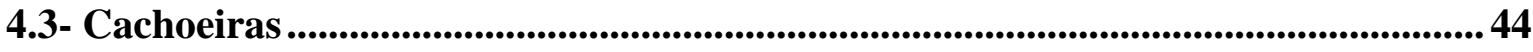

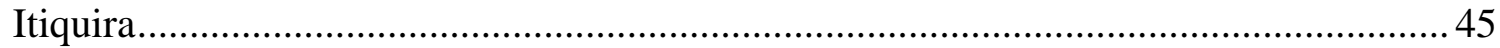

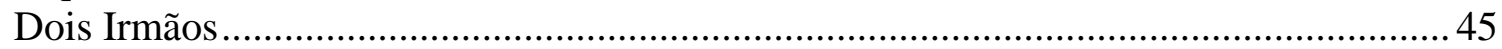

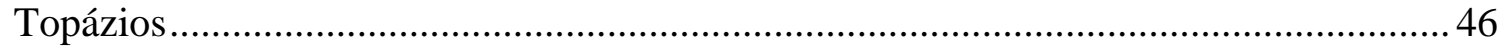

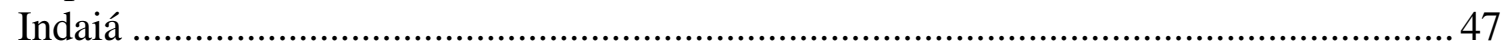

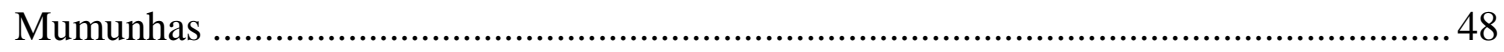

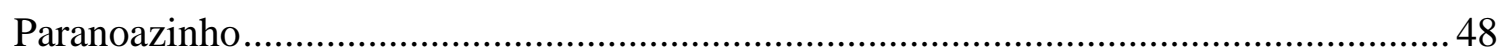

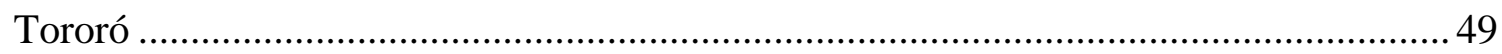

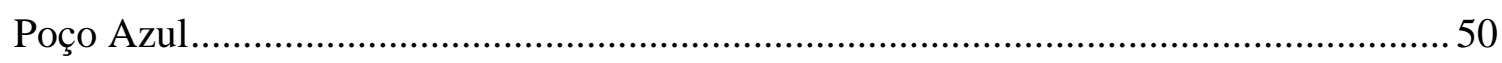

4.4- Estação ecológica de águas emendadas .............................................................................. 50

4.5- Parque Nacional de Brasília - Água mineral .................................................................... 52

4.6- Empreendimentos entorno de Brasília ............................................................................. 53

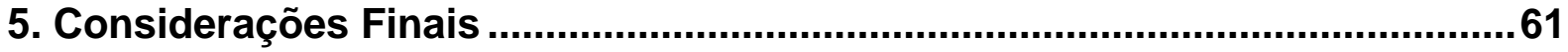

5.1 Vale a Pena

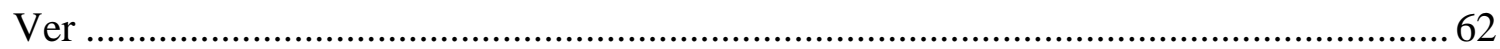

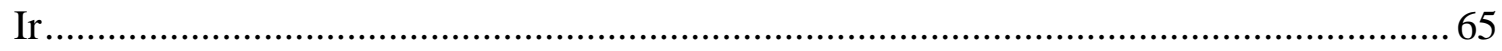

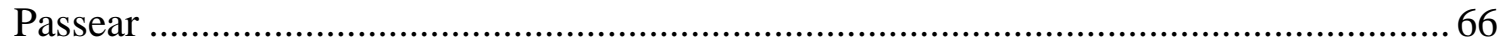

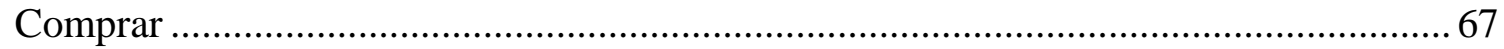




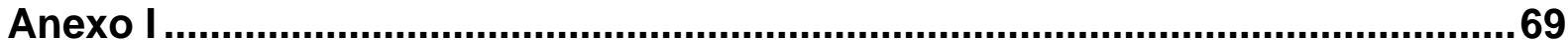

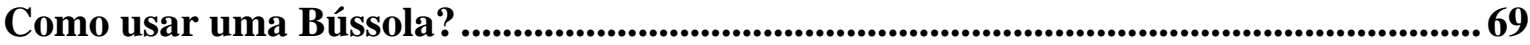

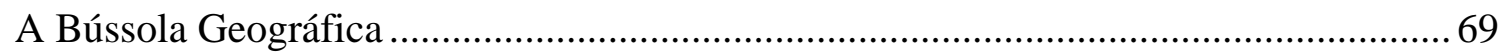

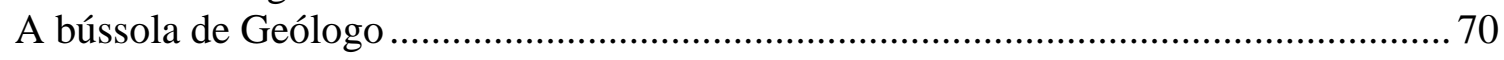

Uma bússola sempre aponta para o Pólo Norte? ................................................................ 71

Uma dúvida sobre polaridade............................................................................................... 72

Para fins de cartografia e orientação, qual o Norte interessa? ......................................... 72

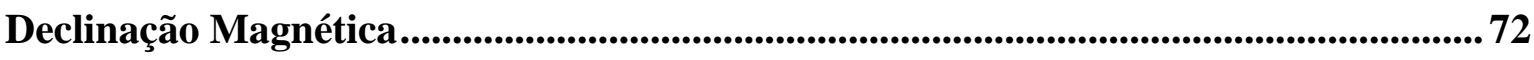

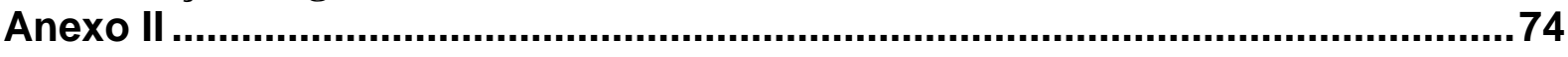

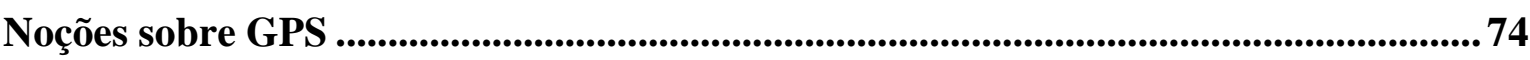

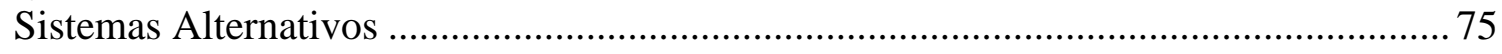

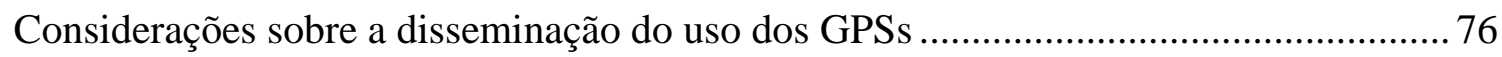

Apêndice ........................................................................................................ 78

Cartografia do DF e entorno......................................................................................................... 78

Cartografia do Tororó............................................................................................................................ 79

Cartografia da cachoeira de Sete quedas .....................................................................................8 80

Cartografia do Poço Azul..............................................................................................................8 81

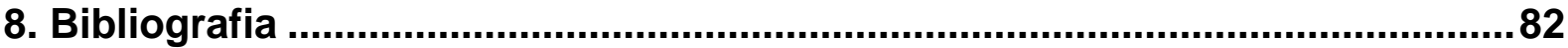

Sites pesquisados .......................................................................................................................... 84

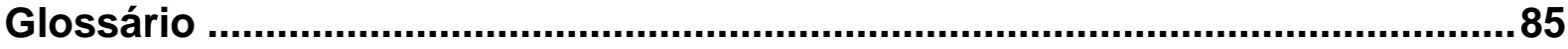




\section{Índice de Figuras}

Figura1- Acqua Rider _ 28

Figura2- Mergulho _ 31

Figura3- Off-Road _ 33

Figura4- Rafting — 35

Figura5- Rapel__ 40

Figura6- Itiquira 45

Figura7- Rio topázios _ 46

Figura8- Indaiá _ـ 47

Figura9- Mumunhas _ 48

Figura10- Chapada Imperial__ 53

Figura11- Fazenda Monjolo __ 54

Figura12- Buriti alegre _ 55

Figura13- Irmão Sol _ 56

Figura14- Agroturismo Florida__ 57

Figura15- Sítio dos Girassóis __ 58

Figura16- Saia Velha__ 59

Figura17- Hotel Fazenda Cabugi _ 60

Figura18 - Bússola geográfica _ 69

Figura19 - Tipos de Bússolas geográficas _ 70

Figura20- Bússola de geólogo__ 70

Figura21- Tipos de GPS _ 77

\section{Fontes:}

- As figuras 1 a 5 foram retiradas do site Ecoviagem.com.br;

- As figuras 6 a 9, foram retiradas do site eco.tur.br;

- As figuras 10 a 17 tem como fonte, o livro turismo rural no DF e entorno (Sebrae, 2003) 100p.

- As figuras restantes foram retiradas do site Gpsglobal. 


\section{Roteiros turísticos de aventura no DF e entorno}

(...) Vários foram os motivos que levaram o homem a se deslocar, como religião, caça, comércio e a educação. Mas, o que permitiu realmente o desenvolvimento do turismo foi o desenvolvimento industrial e as inovações tecnológicas, marcadas pelos períodos modernos e pós-modernos. Durante esses períodos, a atividade de turismo cresceu significativamente, tornando-se um fenômeno industrial (Lickorish \& Jenkins, 2000; Rodrigues, 2001; Córner, 2001 e Urry, 1999).

Após viagem para a Chapada da Diamantina e a Chapada dos Veadeiros podemos verificar o quanto é explorado o Turismo de Aventura, o Ecoturísmo e o Turismo Ecológico de forma sustentável naquelas regiões.

Conhecendo algumas cachoeiras, grutas e vários lugares propícios para exploração do Turismo de Aventura no Distrito Federal, foi levantada a hipótese de se elaborar roteiros para a divulgação destes pontos e seus atrativos naturais.

É possível se elaborar roteiros de Turismo de Aventura para o Cerrado de Brasília e qual a sua abrangência?

Será definida literatura básica sobre o Turismo em geral, seus aspectos, particularidades e estudos de cartografias, tabulação de dados demográfico da região, ênfase na pesquisa teórica, mapeamento dos roteiros através de GPS e estudos dos ambientes através de fotografias.

O turismo é reconhecido hoje em dia como uma atividade econômica de importância global. Vêm crescendo a atenção dada ao turismo pelos governos, organizações, tanto do setor público como do privado, e acadêmicos. Considerado a indústria "sem chaminé", que mais cresce nas últimas décadas no mundo e devido à globalização, o Turismo é o setor da economia mais falado por empreendedores que querem apostar suas cartas em um "negócio" lucrativo. Construção de hotéis, agências e criação ou descoberta de novas formas de explorar esta atividade, o turismo vêm a cada dia crescendo de forma surpreendente. 


\section{Sumário dos capítulos}

- $\quad$ O capítulo 2 descreve a evolução histórica do turismo no mundo e no Brasil, mostra o surgimento do turismo em massa e logo depois, o aparecimento do turismo pós-moderno;

- O capítulo 3 apresenta a história do turismo de aventura, algumas modalidades são citadas e principalmente regras básicas;

- O capítulo 4 descreve os roteiros turísticos no DF e entorno, demonstra as potencialidades do DF e algumas propriedades do entorno que oferece recreação e lazer no meio rural;

- $\quad$ O capítulo 5 apresenta a conclusão e mostra alguns pontos turísticos que vale a pena ver, ir e passear;

- O capítulo 6 é o Anexo, mostra como se trabalhar com GPS e Bússola.

- $\quad$ O capítulo 7 é o Apêndice, apresenta algumas cartografias interessantes do DF e entorno.

- $\quad$ O capítulo 8 mostra a Bibliografia descrita nesse trabalho;

- O capitulo 9 apresenta o glossário, definições de palavras escritas no decorrer do trabalho e abreviações. 


\section{Evolução Histórica da Indústria do Turismo no mundo e no Brasil}

(...) Historicamente, o que existe registrado é que o turismo teve início em Roma imperial, onde existia um padrão amplo de infra-estrutura de viagens, propiciado por dois séculos de paz. As viagens eram desde as muralhas de Adriano até o Eufrates e permitiam aos habitantes das cidades, cansados de uma vida mansa e por estarem sempre à procura de algo que os iludisse, desfrutar de sensações de prazeres cada vez mais novos. Do século XV até o XVII, existiam as excursões organizadas, que iam de Veneza a Terra Santa e que eram consideradas como o fenômeno das peregrinações. Havia, para tanto, as hospedarias para viagens, mantidas por religiosos (Feifer citado por Urry, 1999; Rodrigues, 2001 e Corner, 2001).

Esse século foi marcado pela era artesanal.

(...) No final do século XVII e seguindo pelo século XVIII, além das viagens, iniciou-se o Grant Tour Clássico. Essa evolução da indústria do turismo aconteceu com o início do capitalismo e os primeiros sinais de crescimento industrial e inovações tecnológica. Da referida evolução acarretou a transição da produção artesanal para a manufatura, naquela época nasceu a primeira indústria doméstica na Inglaterra, como produção em rural households. (Urry, 1999; Amato, 2000; Hoffman \& Kaplinsky, 1988).

Posteriormente, em função de seu crescimento e deficiências gerenciais, foram substituídas pelas primeiras fábricas. Decorrente do surgimento dessas fábricas houve um aumento de riqueza que, por sua vez, afetou o modo de vida da população que passou a ter interesse por viagens para outros países, principalmente em busca de educação (o ensino para jovens de boas famílias, filhos da aristocracia e da pequena fidalguia), comércio e saúde. A busca por serviços de saúde resultou nos serviços oferecidos pelos spas, primeiro em balneários e, depois, em áreas litorâneas, pois as águas do mar faziam bem para a saúde, segundo pesquisas daquela época. No século XVIII, atendia aos filhos da classe média profissional com interesse em paisagens e experiências muito mais particulares e apaixonadas pela beleza e pelo sublime. 
(...) No final do século XIX, em função de novas dificuldades gerenciais, como manter os lucros por causa da concorrência, limites para intensificar o dia de trabalho para manter esses lucros e a ameaça de salários reais para mulheres e crianças, ocorreu uma mudança na forma de produção e foram introduzidas as máquinas em substituição à mão-de-obra, dando início à era da maquinofatura e da produção em massa (Hoffman \& Kaplinsky, 1988).

\section{1. $O$ turismo em massa}

(...) No século XIX, aconteceu uma revolução técnico-científica nos campos da eletricidade, do aço, do petróleo e do motor de explosão, além da expansão econômica e a instalação da primeira ferrovia que resultaram em mais empregos e mais renda, especificamente no caso das classes trabalhadoras da indústria do norte da Inglaterra. Além desses fatores, os meios de transportes, como trens e navios a vapor, passaram a ser visto como oportunidades de viagens, viabilizando deslocamentos em massa. Foi o início do turismo de massa, marcado pelos balneários espalhados por toda Europa. (Amato, 2000).

Em função disso, houve um crescimento do turismo e, especificamente, em 1841, sendo lançado o primeiro pacote turístico constituído pelos serviços de transporte, acomodação e a satisfação de um novo e desejado destino - o produto turístico baseado no conceito fordista de padronização, representado pelos acampamentos onde eram oferecidas recreações educacionais, exercícios físicos, artesanato, formação musical, excursões. Férias no campo para crianças carentes.

Os industriais perceberam que férias oferecidas aos trabalhadores aumentavam a eficiência nas indústrias e adotaram tal procedimento estrategicamente. Essa novidade levou ao desenvolvimento de resorts, indústrias de viagens, infra-estrutura de acomodações e uma expansão da capacidade dos transportes e do movimento de tráfego, mesmo com certo atraso e incertezas. Esse movimento se estendeu até a América do Norte. No entanto, já no século XX, entre 1918 e 1939, o crescimento dos serviços de transporte foi interrompido pela Primeira Guerra Mundial, em 1914. 
(...) Justamente nesses momentos de crises e incertezas que se criam os elementos necessários para acontecer transformações estruturais nos diversos campos da ciência, da tecnologia, do comportamento e da sociedade. Foi exatamente o que aconteceu com o turismo que, inesperadamente, teve seus resultados positivos para a prestação de seus serviços, pois a guerra impulsionou a expansão de rodovias e os investimentos em aviações e um incremento das indústrias automobilísticas. Surgiu, então, o turismo social, com novidades como férias pagas, atividades de lazer, campings, campings com traillers, albergues, transportes baratos e turismo em ônibus fretados. O exterior foi o principal foco das viagens. (Amato, 2000).

Novamente, ocorreu uma parada na evolução do turismo, agora marcada pela depressão de 1930 e, finalmente, pela Segunda Guerra Mundial, de 1939 a 1945. Aquela foi a época do ápice dos balneários. Terminado este período, teve início mais uma decolagem do turismo em função da revolução tecnológica e revoluções industriais, que geraram novamente uma aceleração na geração de rendas e que, por sua vez, acarretou em mais mudanças na sociedade. As rendas extras dos países ricos passaram a ser gastas com luxo e serviços. Os serviços oferecidos eram de hotéis, operadoras de transportes, agências de viagem e operadoras de turismo. Aliados às novidades tecnológicas no transportes, surgiram os meios de comunicação que, com a divulgação dos atrativos turísticos via televisão, por exemplo, fizeram com que o turismo se expandisse rapidamente, principalmente nos países ricos, cujos habitantes se interessaram e começaram a viajar mais e preferencialmente em aviões. A mídia proporcionou aos turistas imagens que permitiram a eles selecionar e avaliar os lugares potenciais para visita. As classes mais baixas da sociedade passaram também a se interessar pelo turismo e demandaram outras modalidades, como o turismo desportivo e campings. Instituição especializada, em resposta a esta demanda, se desenvolveram e passaram a prestar estes serviços. Em decorrência da percepção da divisão dessas duas classes, teve início o que se chama, hoje, de segmentação do mercado turístico.

(...) A partir dos anos 1950, iniciou o declínio da era fordista, representado pelas grandes empresas verticalizadas de produção em massa, por várias razões, como trabalho repetitivo que resultou na insatisfação da força de trabalho; consumidores que passaram a demandar algo mais e não apenas os 
padronizados; as fábricas, que eram enormes para serem gerenciadas e a incapacidade de acompanhar as mudanças no ambiente externo. Naquela mesma década, iniciou-se também a queda dos balneários e do turismo em massa. A queda dos balneários deveu-se aos custos de congestionamento, por limites sociais e pela destruição ambiental. Muitas foram às críticas sobre o turismo em massa e, dentre elas, a de que o turismo em massa é ilusão que destrói os próprios lugares que são visitados, cuja causa é um mercado desregulado e turistas medíocres, pouco asseados com péssimos modos e grosseiros (Urry, 1999; Womack et al, 1992 e Hoffman \& Kaplinsky, 1988).

\subsection{O turismo pós-moderno}

(...)Com a queda da maquinofatura, ou fordismo, surgiu, portanto, a mais nova forma de produção no Japão, denominada de produção enxuta de sistemofatura, que acarretou em mais inovações na indústria eletrônica e automobilística. O modelo que veio a ser o centro dessa era foi o just-in-time. Suas características são o mínimo inventário, a flexibilidade para o trabalho, a multifuncionalidade, a inovação, a produção em lotes, o foco na qualidade e um ambiente de trabalho positivo, alcançado pela cooperação, além do uso da nova tecnologia, como a automação, que permitiu a inter-relação intra e interfirmas, ou seja, que deu início à idéia de cooperação internas e externas às organizações, demandando coordenação e proximidade geográfica. Em decorrência desses problemas, mudanças culturais ocorreram, acarretando na reestruturação do turismo. Os turistas, nesse período, passaram a demandar não só os atrativos tradicionais do turismo em massa, como o sol e a areia oferecidos nos balneários, mas também, uma paisagem preservada valorizando o romântico, o lúdico, a nostalgia pelos períodos fortes do passado. (Womack et al, 1992; Hoffman e Kaplinsky, 1988; e Coltman, 1989). 
Surgiu, então, o turismo pós-moderno ou romântico. Aquela fase, denominada pós-moderna ou pós-fordista no turismo ou, ainda, novo paradigma cultural, envolveu diferencial estrutural, desenvolvimento separado de numerosas esferas institucionais e normativas da economia, famílias, estado, ciência, moralidade, etc.

Percebeu-se, nessa fase, que as pessoas têm características e gostos diferentes, pois as paisagens do campo, do meio rural, passaram a ser a atração para o relaxamento, principalmente no período do pós-guerra. As pessoas, quando visitavam esse local, buscavam resgatar as heranças culturais, históricas, se vestindo com os trajes tradicionais, realizando dramatizações entre as maquinarias e equipamentos agrícolas usados na agricultura.

(...)Com a queda do modelo rígido fordista, marcado pelas grandes indústrias, muitas dessas indústrias passaram a ser atrativo turístico, também onde os turistas imaginavam as vidas dos trabalhadores heróicos nas minas de carvão ou nas siderúrgicas. (Urry, 1999).

\subsection{A Indústria do Turismo no Brasil}

A década de 1970, o turismo em massa surgiu no Brasil como uma alternativa viável e importante de desenvolvimento, geração de empregos e rendas.

Naquela época, a indústria do turismo acreditou que o Brasil, por apresentar um acervo ambiental deslumbrante, bastaria para satisfazer a todas as exigências do mercado internacional". (Zimmermann, 1996).

Porém, essa crença era pura ilusão, pois, mesmo apresentando esse vasto acervo ambiental, de hábitos, culturas e tradições, os turistas continuam a viajar para outros lugares do mundo, buscando não apenas um dia ensolarado, mas também serviços profissionais e a um custo razoável.

Em decorrência dessa visão, o modelo da década de 1970 fracassou devido à falta de profissionalização, às crises econômicas e à falta de consciência de três fatores para um desenvolvimento harmônico e sustentável do turismo, que são: a 
preservação do meio ambiente natural e cultural, como aconteceu na Europa; a consciência da importância dos programas de qualidade na prestação de serviços e o reconhecimento da necessidade de formação de mão-de-obra qualificada em todos os níveis e nos diversos segmentos de lazer e turismo (Rejowwski, 1996).

$\mathrm{Na}$ tentativa de superar esses erros, vários atores do setor público, privado e também a comunidade estão investindo em profissionalização, preservação ambiental e cultural, de forma a garantir a satisfação dos turistas, a sustentabilidade da atividade e a competitividade da indústria do turismo.

O Brasil tem sido alvo de turistas e também de prestadores de serviços de turismo, pois, suas regiões apresentam grande potencial. A questão da alta taxa de propriedade estrangeira, contribuindo para a perda de controle dos recursos locais e também da renda obtida com a atividade em países do terceiro mundo. Entre eles, está o Brasil. (Brohman, 1996).

Isso fica bem claro quando são verificados muitos investimentos realizados no Brasil, como, por exemplo, no estado da Bahia, os chamados resorts, como o Transamérica da Ilha Comandatuba, o Club Med de Itaparica e a Praia Eco Resort. Nesses locais vários são os serviços prestados, como lojas sofisticadas, casas noturnas, restaurantes de qualidades, bancos, lanchonetes, teatro, etc., ou seja, procura-se oferecer um pacote com tudo de que o cliente venha a precisar. Há mais cinco projetos de resorts na Bahia, na região de Troncoso, Porto Seguro, Praia de Santo André; no estado do Ceará, o projeto Aquiraz, que retratará uma grande Cancun, com 14 resorts perto de Fortaleza. No estado do Rio de Janeiro existem também os resorts, como o Club Med no Rio das Pedras, em Mangaratiba e outras formas, como os chamados paraísos baratos, nos quais os turistas podem alugar ilhas com amigos a um custo mais barato do que se hospedar em um hotel.

(...)Nessas ilhas, há bangalôs, suítes, piscinas, quadras de tênis e futebol, sauna e heliporto". (Paixão, 1999).

Mesmo com todo esse esforço, as turistas continuam buscando novas alternativas. Umas das tendências hoje no Brasil são os atrativos do setor rural lembrando mais uma mudança acontecida na Europa e América do Norte há muitas décadas. 
A época era marcada pelo turismo romântico e emoções fortes do passado. O turismo rural alia ao produto turístico, características diferenciadoras, que são a nostalgia e a tranqüilidade proporcionadas pela vida no campo.

(...)O turismo no espaço rural é um turismo de espaços naturais e, sobretudo, de espaços humanizados, ativos ou apenas contemplativos, que asseguram um regresso ao passado pela cultura". (Cavaco, 2001).

O crescimento econômico mundial fez com que muitas empresas do setor rural, aquelas de porte pequeno e médio, ficassem à margem, acentuando desigualdades, desertificação humana, gerando incertezas quanto ao futuro desses espaços e sua população, sem perspectiva de desenvolvimento. A conscientização dessa situação, no final dos anos 1980 e a conviç̧ão de que não existem territórios condenados, mas apenas sem projetos, fizeram com que emergisse a concepção estratégica de um desenvolvimento local.

(...) O Brasil vivencia um momento peculiar, caracterizado pela introdução dessa atividade como alternativa de exploração econômica. É uma novidade que está surgindo para os produtores e que pode ser futuramente o alicerce para o desenvolvimento rural. O que está faltando são informações sobre o que realmente oferecer ao turista e como gerenciar essa atividade numa indústria que não tem uma função da produção formal e não tem uma estrutura comum às outras indústrias. Além disso, tem um caráter multidisciplinar e exige uma gestão com cooperação para o desenvolvimento da atividade, além da novidade de produção de um produto intangível (Oliveira, 1997).

Essa deficiência de conhecimentos pode resultar em estratégias mal elaboradas e vir a interferir negativamente no desenvolvimento da atividade. As conseqüências disso podem ser a descaracterização, tanto do espaço como do homem rural, visto que seus valores intrínsecos podem perder-se ou, pelo menos, serem alterados; a falta de competitividade e, por fim, o agravamento da situação das empresas do setor rural, como ocorreu com o turismo de massa no passado. 


\section{3- Turismo de aventura}

A modalidade de turismo denominada turismo de aventura, constitui-se em um dos alicerces na tentativa de alcançar um modelo mais completo para o desenvolvimento de várias modalidades do turismo, uma das mais fortes delas o turismo ecológico, principalmente em se tratando de estarmos em um país com predominâncias exuberantes no que tange a biodiversidade em geral.

O termo Aventura vem do Latim e quer dizer (Adventura, do latim "o que há por vir") quer dizer, trata-se de manter as fortes emoções como fator predominante na realização de qualquer atividade deste segmento.

A dificuldade de escrever sobre um tema onde não existe ainda nenhum trabalho dirigido, é que, apenas o Instituto Brasileiro de Turismo - Embratur, promoveu através da diretoria de fomento e departamento de projetos especiais, uma oficina de planejamento, no período de 16 a 19 de abril de 2001, com o objetivo de elaborar um Plano de Ação subsidiando a fundamentação de uma Política Nacional de Fomento ao Turismo de Aventura e de conceber a estrutura básica de um Guia Nacional de Turismo de Aventura e de um Manual de Orientação aos Municípios.

O trabalho da Embratur abordou de forma tecnicista o assunto, mas mostrouse como um dos pioneiros na área no Brasil e começa a tratar do turismo de aventura como partes que se dividem em três analises e que depois se fundem em apenas um conceito e de acordo com a análise I é;

Deslocamento de pessoas com vistas a praticar atividades de aventura, com orientação técnica, respeitando as habilidades individuais, os níveis de capacitação e as condições ambientais são segmento do turismo que exige especialização técnica específica para vivenciar atividades "outdoor", consignado em nível de capacitação e habilidade individual. (Embratur, 1994).

A Embratur trabalha com o tema da maneira como os primeiros estudos relacionados com a conceituação do turismo, com uma abordagem bastante 
superficial, é tão verdade que confronta a realização desta modalidade que deveria ser para qualquer turista possível, com a necessidade de ser especializado nesta área para poder praticar este ou aquele turismo de aventura.

Já na análise II, da um tratamento ao assunto de maneira mais direta mais ainda falta tratar do meio social em que se insere o termo;

Prática de atividade física na natureza, com riscos previstos, com orientações prévias do ambiente natural e os equipamentos utilizados (Embratur, 1994).

A próxima análise a III tem como base uma abordagem que mescla o técnico ao social e já demonstra uma certa maturidade no que diz respeito a este conceito e diz;

Segmento que contempla atividades e esportes na natureza de modo recreacional, seguro e ambientalmente sustentável, eventualmente / freqüentemente, envolvendo esforço físico e risco controlável, orientados e monitorados por técnicas e profissionais treinados / capacitados e equipamentos adequados, que vem ao encontro da demanda por lazer ativo e desafio".(Embratur, 1994)

Estes conceitos geraram a partir daí uma definição específica, que é utilizada pela Embratur e esta baseada em termos técnicos, mas com bases sociais e complementação as definições até agora apresentadas sendo esta a melhor definição de turismo de aventura já realizada até os dias atuais sendo o;

Segmento do mercado turístico que promove a prática de atividades de aventura e esporte recreacional, em ambientes naturais e espaços urbanos ao ar livre, que envolvam emoções e riscos controlados, exigindo o uso de técnicas e 
equipamentos específicos, a adoção de procedimentos para garantir a segurança pessoal e de terceiros e o respeito ao patrimônio ambiental e sócio cultural.(Embratur, 1994)

Em outra abordagem do assunto, Mourão diz que;

É o segmento do turismo constituído por programas e atividades com conotação de desafio, expedições acidentadas, na maioria das vezes para adultos, envolvendo viagens arrojadas e imprevistos. Exemplos: escaladas, espeleologia, jeep safáris. (Mourão, 2002).

O Termo é trabalhado como se fosse uma atividade qualquer sem fundamentação teórica ou cientifica, apenas dizendo o que acha a respeito do turismo de aventura, sem citar referências ou analisar de maneira correta o termo, o que leva a crer e mostra ser verdade a pouca existência de estudos e materiais sobre esta nova atividade que poderiam elucidar questões até simples como a sua momentânea conceituação.

O turismo de aventura a atração são os exercícios físicos em situações de desafio, em ambientes naturais, onde podemos verificar uma "conceituação" tratando apenas da questão radical e se esquecendo do lado social, cultural e ambiental do segmento. (Uvinha, 2001)

Finalizadas as conceituações mais consagradas existentes na área sobre Turismo de Aventura, a melhor delas é sem dúvida a realizada pela Embratur, ressaltando, que ela foi realizada quando da reunião de inúmeros praticantes de atividades radicais e empresários da área, graças ao apoio dado pela Embratur (financeiro) e pode de uma vez só, realizar uma pesquisa quantitativa e qualitativa sobre esta nova modalidade de turismo e que esta alocada no Plano Nacional de Desenvolvimento Sustentável do Turismo de Aventura.

Tratar desta questão é tão verdade que no turismo de aventura se encaixam nele várias modalidades dos esportes radicais, para elucidar e acrescentar a esta questão temos quando o conceito diz que, apenas, espaços urbanos ao ar livre, exclui a possibilidade da realização de turismo de aventura em ambientes internos e controlados, como, por exemplo, na prática do arborismo, que é uma 
modalidade onde se mesclam técnicas de escalada, rapel e tirolesa e pode ser adaptado para dentro de um centro de convenções como foi realizado na Feira e Convenção Adventure Sports Fair 2002 em São Paulo no Pavilhão da Bienal. Onde foi montada uma gigantesca rede de Arborismo dentro da própria feira, onde os visitantes que neste caso poderiam ser tratados como turistas realizavam a prática desta atividade, daí podemos imaginar uma atividade destas ser montada dentro de um hotel durante um feriado chuvoso atendendo a demanda turística por meio do Turismo de Aventura sem frustrar tanto as expectativas dos clientes.

Deste modo devemos acrescentar a definição dada pela Embratur ao Turismo de Aventura às palavras “... ao ar livre ou não...” deixando assim a conceituação deste termo adequada até o momento já que no turismo o dinamismo e as mudanças são constantes, que pode ser que amanhã este conceito tenha que ser modificado como é de se esperar.

Elucidada a conceituação de Turismo de Aventura, deve-se também quando se trata deste assunto, trabalhar em conjunto com o segmento do turismo ecológico de estreita ligação com o tema abordado e fundamental cada vez mais para o constante crescimento do turismo de aventura.

\section{1- Como surgiu o termo turismo de aventura?}

Os esportes radicais como são chamados os esportes de ação, são aqueles onde os riscos e a possibilidade de ocorrência de um acidente grave ou fatal estão diretamente e muito perto de acontecer durante a realização destas atividades.

Então o que é uma atividade radical? É qualquer uma que ofereça "risco" à integridade física do praticante. Gostaria de incluir na lista de atividades radicais, atravessar o eixo monumental, tanto o norte como o sul nos horários de "pico".

Esta modalidade de esporte surgiu a partir de meados do século XVIII com o início do montanhismo ou chamado de montanhismo embrionário. É tão verdade que foi a partir da escalada a grandes altitudes, hoje chamada de 
escalada aos picos de neve eterna como a primeira registrada a grande altitude, realizada no cume do MONT BLANC com 4807 metros de altura nos Alpes na França em 1776, que iniciou um esporte chamado Alpinismo.

(...) Alpinismo é um neologismo criado para designar a ascensão ao cume de montanhas localizadas na cadeia montanhosa dos Alpes na Europa. Sendo que estas são escaladas de grande extensão, realizadas por pequenos grupos de não mais que três a cinco pessoas, e em geral com visual espetacular. Podem ou não incluir trechos com progressão em artificial, e também em gelo. Esta é uma modalidade de extrema exposição às condições ambientais. Nela conhecimentos como, meteorologia, navegação, nutrição esportiva e até primeiros socorros são fatores importantes para o sucesso e a sobrevivência. (Franzen, 1998).

Assim foi o primeiro esporte, a ser considerado por esportistas em geral no mundo todo como um esporte radical, pois o risco estava diretamente ligado à prática desta modalidade. Fascinando muitos adeptos, as montanhas foram sendo conquistadas e motivaram o aprimoramento de equipamentos e técnicas utilizadas para a subida e descida de montanhas de acordo com as dificuldades encontradas, tais como clima, altitude, tipos de rocha e demais variantes que não cabe serem citadas neste estudo. Do montanhismo apenas para se tomar como referência e exemplo, surgiu o Pára-glaider ou Pára-pente como chamado aqui no Brasil, ele era utilizado para ao se conquistar o cume de alguma montanha ao invés de descer pelos métodos convencionais desescalando a montanha 0 esportista inflava seu pára-pente e descia voando desde o cume até a base da montanha.

Dos esportes considerados radicais que são inúmeros e já tem sua fatia de modalidades pré-classificadas, já são e foram definidos por esta terminologia a mais de 200 anos (não todos os esportes no caso aqui citado apenas o primeiro o montanhismo).

A partir de 1990, com menor expressão, e agora no começo deste milênio, com força significativa, iniciada pela grande demanda gerada pelo turismo interno decorrente da alta do dólar ocasionada pela instabilidade das maiores economias do mundo e inclusive do Brasil neste caso, uma nova modalidade de turismo veio à tona com fortes tendências dos esportes radicais. Isto por ser realizada sem se sair do território nacional a um custo relativamente menor do que se tem em viagens realizadas para o exterior. 
Esta nova modalidade do turismo vem sendo chamada de Turismo de Aventura, e nasceu da introdução de esportes antes exclusivamente praticados por esportistas radicais natos e fascinados pela emoção e riscos. Algumas modalidades dos esportes radicais foram trabalhadas e remodeladas para aumentar a segurança e controlar as variáveis no que tange a riscos e acidentes imprevisíveis, para uma situação onde podemos chamar a atividade de apenas potencialmente perigosa.

(...) Neste caso o risco ainda existe é claro, mas se mantém entre "linhas de segurança", que não podem ou devem ser ultrapassadas. É como estar em uma pista de corrida dirigindo um carro super potente a alta velocidade e em uma curva muito acentuada não diminuir a velocidade deste carro para realizá-la com precisão, o que vai acontecer é que você vai se acidentar. É esta a questão da atividade potencialmente perigosa, se você se mantiver entre estas linhas de segurança é claro que vai realizar qualquer atividade com segurança tirando proveito dela. (Franzen, 1998)

Deste modo surge o termo Turismo de aventura, quando, a partir do momento em que empresas de agência turística começam a introduzir algumas modalidades dos esportes radicais como meio de se tornar uma atividade lucrativa e tem nesta atividade uma resposta animadora por parte da demanda dos turistas por este tipo de atividades.

Com estes esclarecimentos, podemos perceber que o Turismo de aventura surgiu dos Esportes radicais, e neste caso se tratando de uma pesquisa científica obrigatoriamente tem que estar ligados até pelo menos esta diferença estar definitivamente esclarecida na concepção dos que trabalham com a divulgação turística, além da necessidade de mais pesquisas serem realizadas com o intuito científico para sanar quaisquer dúvidas a respeito desta nova modalidade do turismo. 


\section{2- Crescimento do Turismo de Aventura no Brasil}

É assustador o modo como o mercado de esportes de aventura vem crescendo no Brasil. A cada dia que passa, novos destinos e modalidades surgem como novo produto em empresas especializadas nesse ramo. Porém, um detalhe, aparentemente simples, marca e caracteriza tais produtos: o ambiente onde são praticados é quase sempre o natural. Rios, vales, montanhas, riachos, cachoeiras, picos e chapadas possuem características que propiciam a prática das atividades como Rafting (descida de rios com corredeiras a bordo de botes infláveis), Escalada, rapel (técnicas de descida em obstáculos verticais), trekking (caminhada com pernoite), cavalgadas, etc. Isso faz com que essas "empresas especializadas" divulguem tais produtos como prática de Ecoturismo. Será correto?

Analisando mais a fundo tal acontecimento é importante que notemos dois importantes detalhes. Em primeiro lugar, o verdadeiro motivo que leva determinada pessoa a praticar o turismo de aventura, que consiste em adaptar atividades de esportes radicais para uma prática turística, permitindo que qualquer pessoa, mesmo sem conhecimento técnico ou experiência nenhuma, sinta a sensação e emoção de um praticante experiente e treinado. E em segundo lugar, porém não menos importante, o formato adotado pelas empresas nos pacotes e produtos de turismo de aventura.

Ao procurar um pacote ou roteiro de turismo de aventura o "turista radical" quase nunca tem como objetivo conhecer determinado destino e ter um contato mais íntimo com o ambiente. Suas expectativas giram, na maioria das vezes, em torno de obter experiências emocionalmente diferentes, aliviar stress e estimular sentimentos e sentidos "esquecidos" na dura rotina de cidades grandes, como solidariedade e liderança, através do vencimento dos desafios e medos sugeridos durante a prática do turismo de aventura.

(...) Não se pode deixar de reconhecer que esses sentidos são muito importantes para qualquer pessoa e que o turismo de aventura é uma excelente ferramenta para estimular tais sentidos. Porém, o formato dos roteiros de turismo de aventura deveria oferecer aos clientes muito mais do que ele procura, como 
por exemplo, a integração com o contexto local (cultura, economia, meio ambiente natural e urbano, etc). (Franzen, 1998)

A integração com o meio ambiente natural e cultural de determinado destino, dá ao turista o conhecimento sobre ecossistemas, costumes locais, "causos", folclore, etc., contribuindo tanto para a reflexão dos turistas em relação à sua postura quando em contato com culturas diferentes e quanto para o respeito e valorização dos limites dos ecossistemas naturais.

Com o grande e crescente número de pessoas que viajam em busca de atividades radicais, nota-se um grandioso desperdício de oportunidade em promover experiências mais ricas sob o ponto de vista humano e que são capazes de contribuir para a formação de uma consciência ambiental mais responsável dos participantes.

Esses são alguns dos motivos que constatam que o termo Ecoturismo talvez não esteja sendo corretamente utilizado por empresas especializadas em Turismo de Aventura. Grande parte delas oferece apenas adrenalina, enquanto poderiam oferecer também, através de experiências, informações que valorizem o meio que o turista está inserido para a prática de determinada atividade. Se visitar uma área natural sem o propósito de integração for considerado ecoturismo, teremos no Parque do Ibirapuera, na cidade de São Paulo, milhões de "ecoturistas" que, durante todos os dias visitam as áreas naturais desse parque metropolitano em busca, apenas, de eventos culturais e atividades físicas (fitness). Ou então, se a prática de turismo de aventura for considerada ecoturismo, teremos no Viaduto da Dr. Arnaldo, no bairro do Sumaré, também em São Paulo, milhares de "ecoturistas" que praticam o rapel em um ambiente totalmente urbano.

Não podemos considerar o rafting, por exemplo, como ecoturismo, a menos que durante sua prática, sejam passadas pela empresa que promove a atividade informações como micro-bacia hidrográfica em que estão inseridos, impactos decorrentes da atividade que praticam, vegetação, importância da presença do turista para a economia da população local, etc.

Por outro lado, a acirrada concorrência entre as empresas de turismo de aventura e a demanda existente por esse segmento, impedem que essas empresas modifiquem o atual formato dos produtos que dispõem. Como citado anteriormente, o cliente está em busca de Turismo de Aventura e não de Ecoturismo. 
Portanto, comercialmente falando, porque promover Ecoturismo? Talvez já saibamos a resposta.

\section{3- Modalidades de Aventura}

\subsection{1- Acqua Rider}

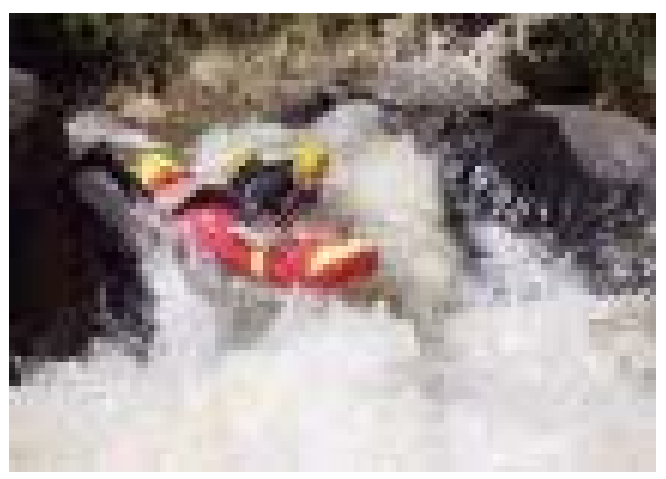

Figura1- Acqua Rider

Fonte: Site <www.ecoviagem.com.br>

O Acqua Rider é um esporte praticado em corredeiras de rios, onde o atleta se posiciona de peito em um mini bote inflável enfrentando o desafio que a natureza das águas brancas apresentam. Este esporte, totalmente Brasileiro, nasceu na década de 70 com a brincadeira de se jogar com câmaras de ar nas águas brancas do Rio Betary, no vale do Ribeira após uma exploração nas cavernas do Parque Estadual do Alto do Ribeira (PETAR), esses amantes da natureza aproveitavam para dar uma "descida no rio".

Tudo não passava de uma brincadeira, mais um dia um velho amigo do grupo "Rider" no ano de 1984, idealizou o primeiro campeonato de Acqua Ride. Á partir daí todos os anos no carnaval, acontecia o Campeonato Brasileiro de Acqua Ride com participação de pessoas de vários lugares. Existia Também um grupo de Jundiaí (SP), que além de tomar parte dos primeiros campeonatos, já começava a explorar novos rios para praticar o esporte e usar equipamentos de segurança, (capacete, joelheiras, colete salva-vidas, caneleiras, roupa de neoprene e o "mini bote"), começando assim profissionalizar e evoluir. 
Por ser um esporte nacionalíssimo quem vem à frente com a organização de campeonatos é Associação Brasileira de Acqua Ride (ABAR), e que está sendo reconhecida pelas Confederações Paulista e Brasileira de canoagem, dando assim ao Acqua Ride a profissionalização e reconhecimento como esporte.

\subsection{2- Arborismo}

O Arborismo, popularmente conhecido como Arvorismo, é um esporte radical recém chegado ao Brasil que faz sucesso no mundo todo, principalmente na Nova Zelândia - considerada a capital mundial dos esportes radicais. Essa nova modalidade esportiva consiste na travessia de um percurso acrobático realizado próximo à copa das árvores, utilizando-se diversas atividades de técnicas verticais, como a tirolesa e o rapel.

O praticante precisa vencer vários obstáculos e percorrer diferentes circuitos suspensos a alguns metros de altura do chão. Após receber instruções da equipe de monitores, o participante caminhará entre a copa das árvores progredindo a medida em que evolui nos estágios de dificuldade de cada trajeto. A dificuldade vai crescendo ao longo das sessões, o que permite uma adaptação gradual à altura.

Todas as pessoas, inclusive crianças a partir de quatro anos (com equipamentos adequados e específicos a essa idade), podem praticar o Arborismo, pois não é necessária nenhuma experiência anterior.

Coordenação, equilíbrio, concentração e confiança são algumas das habilidades que você desenvolverá no Arborismo.

A técnica de utilizar redes e pontes feitas com cabos e cordas na altura das árvores e caminhar entre elas surgiram a muito tempo, da necessidade de cientistas observarem flores e animais que aí vivem, e no treinamento de militares e escoteiros.

A modalidade de esporte de aventura e natureza só foi surgir em 1995, nos Alpes da França, como uma decorrência natural da técnica desenvolvida anteriormente. 
No Brasil, o esporte surgiu recentemente, com o Verticália desenvolvido em 2001 na cidade de Brotas. Porém, tem-se registro de um escoteiro no Rio Grande do Sul, na década de 60, fazendo falsa baiana entre árvores...

Quase 10 anos depois do surgimento do primeiro circuito de arborismo na França, muita coisa mudou: técnica, equipamentos e jurisprudência.

Pontes e escadas de tronco, falsa baiana, trapézios, $X$, tirolesa e rapel controlado são alguns dos desafios encarados no Arborismo.

Para preservar as árvores, que são parte integrante da estrutura do circuito, alguns cuidados especiais devem ser tomados: nada de furos nos troncos, monitoramento do seu crescimento, respeito a espécies protegidas e às leis ambientais. Esses cuidados, que têm um certo custo no começo, se tornam um marketing positivo em longo prazo para as operadoras.

Para a montagem dos circuitos, basta um espaço aberto com uma bela natureza e o uso das técnicas e cuidados adequados. Para praticar o esporte, é necessário o kit arborismo, composto por capacete, cadeirinha, costura, mosquetões e roldana (polia).

O percurso é inteiramente seguro por cabos independentes da estrutura de progressão. A segurança também é garantida por um cabo vida, que percorre todo o circuito por cima. Os praticantes estão o tempo todos conectados a este cabo de aço através de uma fita solteira e 2 mosquetões (sistema da solteira dupla).

O praticante é autônomo para manipular os equipamentos, mas um monitor supervisiona todas as manobras, que consistem no uso correto da solteira dupla e da polia. 


\subsection{3- Mergulho}

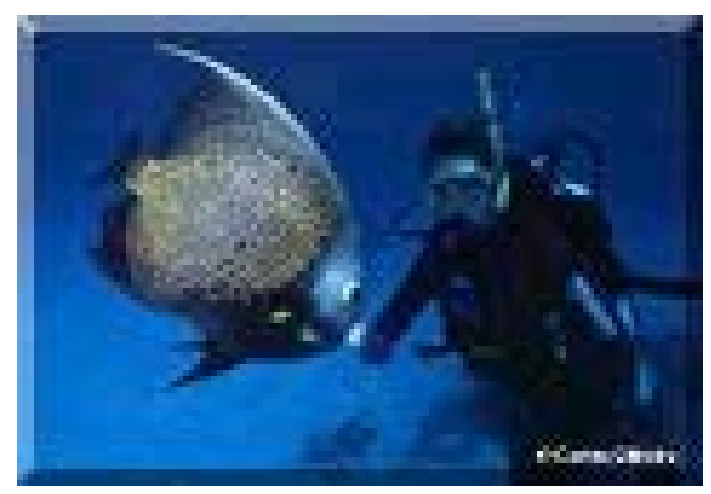

Figura2- Mergulho

Fonte: Site <www.ecoviagem.com.br>

Conhecer novos lugares é uma experiência fascinante. Imagine então poder conhecer um mundo totalmente diferente do que você está acostumado a ver. É exatamente isso que o mergulho proporciona: estar no mundo das águas, podendo ver de perto a vida marinha com todas as suas cores e mistérios. $O$ fundo do mar ou as cavernas e grutas de água doce guardam encantos que só o mergulho nos permite descobrir.

\section{Tipos de cursos}

Mergulho Básico é um curso para quem deseja iniciar a prática deste esporte. Inclui uma parte teórica e outra prática, com aulas em piscina e no mar. As aulas teóricas englobam a física do mergulho, equipamentos, fisiologia do mergulho, tabelas de descompressão, planejamento do mergulho, sinais e toda a técnica e procedimentos relativos ao mergulho. A prática inclui treinamento em piscina e, por fim, o check out ou batismo no mar, com supervisão do instrutor.

Mergulho Avançado Para quem já se iniciou no mundo do mergulho, este curso oferece novas opções em quatro modalidades: Mergulho noturno: Fornece a 
técnica e procedimentos adotados nos mergulhos noturnos; Mergulho Profundo: Permite a realização de mergulhos em maiores profundidades; Orientação Submarina: Ensina a orientação, tendo o meio ambiente como referência ou através de equipamentos. Busca e Recuperação - destina-se à busca e recuperação de objetos perdidos no fundo do mar. Vale lembrar que, conforme a credenciadora ou local de realização deste curso, as especialidades podem ser alteradas, assim como o número mínimo exigido.

\section{Tipos de Mergulho}

Mergulho Livre Para este tipo de mergulho não é necessário nenhum tipo de curso e o equipamento é muito simples: máscara, snorkel e nadadeira. Em lugares com boa visibilidade, você flutua enquanto observa as belezas que estão debaixo d'água. Os mais corajosos podem submergir em pequenas profundidades, o que é conhecido como apnéia. Para os que tiverem interesse em aprofundar-se na atividade há cursos com credenciamento para Snorkeling. Mergulho Autônomo Este tipo de mergulho exige preparação e equipamentos especiais, já que deixa a superfície e nos permite permanecer bastante tempo debaixo d'água em grandes profundidades. O equipamento mínimo necessário é: um cilindro com ar comprimido (reservatório de ar para o mergulhador), um regulador (equipamento que regula a saída de ar para que o mergulhador respire sem esforço, independente da profundidade em que se encontra), um relógio de mergulho para controlar o tempo de permanência, um profundímetro para controlar a profundidade, um manômetro para controlar quanto de ar ainda resta no cilindro e um colete equilibrador, que proporciona o controle da flutuabilidade durante o mergulho, prende o cilindro junto ao corpo do mergulhador e dá flutuabilidade na superfície. Para realizar o mergulho autônomo existem umas séries de cursos. 


\subsection{4- Off-Road}

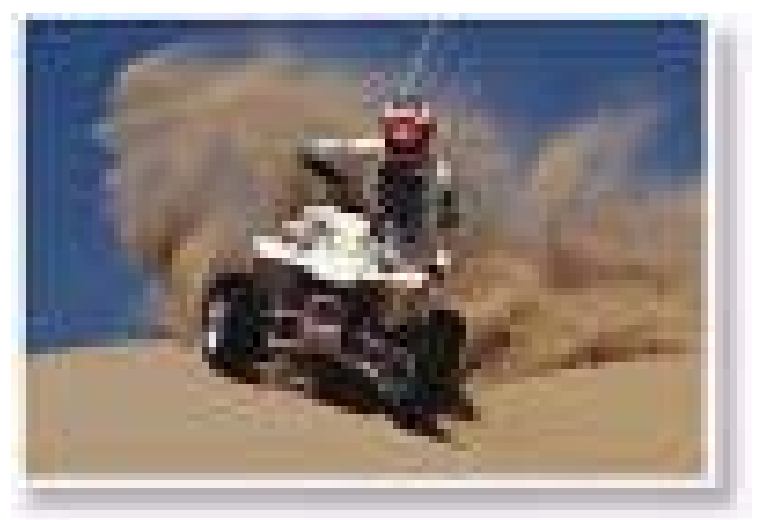

Figura3- Off-Road

Fonte: Site <www.ecoviagem.com.br>

O espírito de aventura é o que leva as pessoas a praticarem o off-road ou "fora de estrada". O objetivo é percorrer caminhos não convencionais, difíceis e, algumas vezes, aparentemente intransponíveis, como trilhas, rios e barrancos.

A recompensa é o contato com paisagens belas e raras e, dependendo dos obstáculos naturais encontrados pelo caminho, é também muita adrenalina.

O que caracteriza um verdadeiro off-road é o sistema de tração nas quatro rodas, mais conhecido como $4 \times 4$, além dos diversos equipamentos opcionais que variam conforme a modalidade praticada.

Esses mecanismos, aliados à robustez do veículo, são necessários para que muitos dos destinos visados sejam alcançados. Sem eles, a ultrapassagem de alguns trechos do trajeto seria impossível.

O Off-Road, tanto de passeio como de competição, pode ser praticados em percursos naturais ou construídos (indoor), tais como estradas vicinais, Rodovias, pastagens e trilhas.

Os primeiro modelo "fora de estrada" apareceu em 1910. Nas décadas seguintes, veículos desse porte foram fabricados com objetivos militares. No Brasil, chegaram na década de 40 para puxar o arado nos trabalhos rurais, ocupando a função que hoje é exercida pelos tratores, inexistentes na época.

Quase meio século se passou para que o primeiro Jipe Clube nacional fosse criado. Em 1985 foi fundado o Jipe Clube do Brasil, que dois anos mais tarde 
promoveu a primeira competição de off-road no país, um rally de regularidade. A partir daí, o interesse dos brasileiros por "foras de estrada" não parou de crescer.

O bem estar proporcionado pelo contato com a natureza e o prazer de pilotar um 4x4 em caminhos não convencionais têm despertado o interesse de pessoas que fogem à imagem do jipeiro tradicional. Famílias inteiras estão descobrindo no off-road de passeio uma nova opção lazer, desmistificando a idéia de que é uma prática agressiva e exclusivamente masculina.

Dentro da modalidade de passeio encontram-se ainda as expedições, viagens geralmente realizadas por um grupo de amigos que vivenciam o espírito off-road, em busca de emoção e, muitas vezes, cultura, pois acabam entrando em contato com diferentes comunidades.

As competições evoluíram bastante desde 87, onde são avaliadas, basicamente, a velocidade e a constância dos veículos, que muitas vezes dependem da sintonia entre os membros da equipe.

A velocidade e a dificuldade do trajeto e de seus obstáculos varia de acordo com a radicalidade e o conhecimento técnico do praticante de off-road, que dispõe das seguintes modalidades esportivas:

Raid ou Rally de Velocidade: O veículo deve percorrer o trajeto aproximando-se ao máximo da velocidade e do tempo médios pré-determinados para cada trecho. Para isso, conta com o auxílio indispensável do navegador, que interpreta as informações obtidas por diversos instrumentos que citaremos adiante.

Rally Cross Country: É caracterizado pela dificuldade dos obstáculos do percurso, que deve ser transposto no menor tempo possível.

Indoor: Corrida contra o cronômetro praticado numa pista artificial, lamacento e cheia de obstáculos.

Rally de Turismo: É como um cross country menos radical, ou seja, o que vale é a velocidade, mas num caminho bem menos acidentado. 
O navegador é essencial para a prática segura e bem sucedida do off-road. É ele quem orienta o piloto sobre o percurso, suas dificuldades, a velocidade média a ser mantida, etc. Para isso, conta com o auxílio de diversos instrumentos de navegação, tais como:

Mapas: Ajudam na localização e, através da indicação de altitudes, permitem identificar o tipo de relevo a ser percorrido.

Planilhas: De grande importância nas provas de regularidade, descreve o trajeto minuciosamente, indicando quilometragens e avisos relevantes.

Computador de Bordo: Auxilia na obtenção de diversos dados como quilometragem e velocidade média, pois indica, basicamente, à distância percorrida pelo veículo.

GPS (Global Pointing Sistem): Através de informações fornecidas por satélites, indica a posição exata onde o veículo se encontra, além de registrar sua velocidade média, distância entre pontos, etc.

\subsection{5- Rafting}

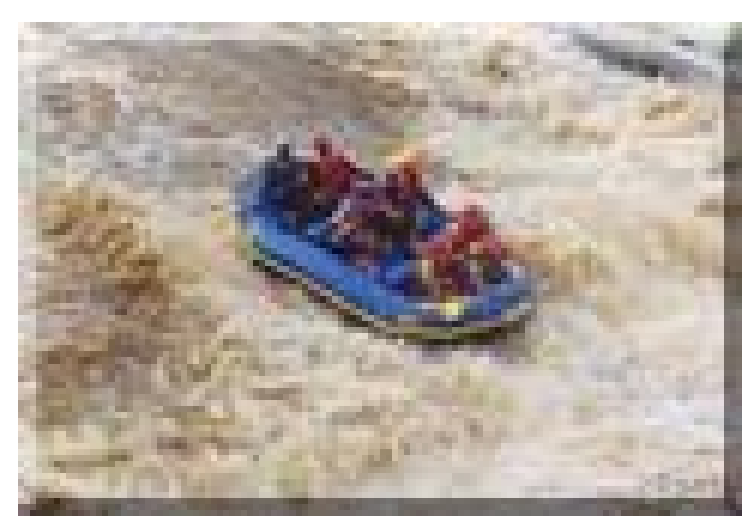

Figura4- Rafting

Fonte: Site <www.ecoviagem.com.br> 
Frente, ré, piso! Enquanto o instrutor dita os comandos, os remadores procuram o sincronismo. O trabalho em equipe é fundamental para vencer uma corredeira. E corredeira significa velocidade e água. Não saber o que vem pela frente causa expectativa e muita adrenalina. Concentração e integração garantem que o bote vença as corredeiras e, principalmente, não vire. A sensação de ter passado por uma queda d'água causa um certo orgulho, que não é individual, é de todos. Remo para cima, grito de guerra e lá vai o bote seguindo pelo rio.

Para descer um rio, sempre na companhia de uma instrutora, basta saber alguns comandos e remar junto com seus companheiros de bote. O sucesso desta operação depende do conhecimento que o instrutor tem de uma linha segura (caminho seguido pelo bote na corredeira) e da sincronia do grupo. Comandos de remada: frente, ré, direita ré/esquerda frente, esquerda ré/direita frente e parou. Comandos de posicionamento: segura, piso, peso à esquerda, peso à direita, peso à frente e peso atrás. A dificuldade de um rio é medida pela classe das corredeiras. Cada trecho de um rio pode apresentar uma classe. Ao todo, existem seis classes, sendo a I a mais fácil e a VI a mais difícil. As corredeiras de classe VI são inavegáveis.

A qualidade dos equipamentos importados ainda é superior aos nacionais, apesar da grande evolução destes nos últimos anos.

Colete com classe de flutuação Os praticantes consideram os coletes aprovados pela marinha americana os melhores. O colete com maior flutuação é para rios de classe cinco, sendo o mais seguro de todos. Os nacionais estão melhorando bastante, mas apresentam alguns problemas, como por exemplo, descosturar e embolorar com mais facilidade.

Remo Os remos com cabo em $\mathrm{T}$ proporcionam uma posição mais confortável para remar.

Capacete É importante que os capacetes sejam ajustáveis para cada cabeça, tenham proteção para as orelhas, furos para permitir fluxo de água e fita de fixação. 
Bote existem três bons fabricantes nacionais: Zefir, Arboat e Flexboat. A grande diferença está nos tecidos utilizados. (os importados são de Haypalon, e os nacionais, de PVC).

Remos individuais Cada pessoa do bote possui um remo e todos remam juntos. É a modalidade mais praticada no Brasil. Oar Boat Apenas uma pessoa controla um par de remos longos que fica preso em uma estrutura de alumínio sobre o bote.

É difícil falar em segurança já que não existe nenhum órgão de regulamentação ou fiscalização atuante. Com os equipamentos nacionais apresentando um preço mais baixo, tornou-se fácil abrir uma empresa. Como saber, então, se uma operadora de rafting está preparada para qualquer situação de perigo dentro de um rio? Primeiro, procure observar qual equipamento utilizado. Os coletes devem ter uma boa flutuação, ou seja, a classe deve ser igual ou superior ao nível das corredeiras. Além disso, eles devem ser aprovados para Rafting/Canoagem pelo órgão competente do país do qual se originam (no Brasil é o IPT e a marinha). Todos os botes devem portar um cabo de resgate com pelo menos $20 \mathrm{~m}$ de extensão. Um dos botes deve possuir kit de primeiros socorros completo. Uma boa opção é que os botes tenham "finca pé", um tipo de alça no piso para prender o pé, diminuindo a chance de queda e o sistema de auto-esgotamento (saída de água) chamado self-bailer. É fundamental que os instrutores tenham uma boa experiência e conheçam bem o rio que estão descendo, além de dominar os sinais que utilizam apito, remo e mão, seguindo normas internacionais. A formação dos instrutores varia bastante em cada operadora. O ideal é que as empresas possuam uma escolinha, em que o aluno aprenda tudo sobre o esporte, como tratar o cliente e como fazer resgate e primeiros socorros, através de aulas teóricas e práticas. Se ele for considerado apto, passa a ser estagiário, indo para o rio com instrutores mais experientes, até que se torne um instrutor. A boa preparação de um instrutor é imprescindível no caso de alguém cair do bote em uma corredeira. O credenciamento dos instrutores está sendo planejado e organizado pela IRF - Intenational Rafting Federation. Esta entidade tem aproveitado os campeonatos para formar os 
chamados líderes de continente, que serão os responsáveis pelo credenciamento em cada país.

\subsection{6- Trekking}

Na tradução para o português, a palavra trekking quer dizer caminhar, trilhar, andar. E, na maioria das práticas esportivas em ambientes naturais, ele é freqüentemente utilizado, ou para se chegar até uma cachoeira no meio do mato, para se alcançar o topo de uma colina em que o visual é imperdível, e até mesmo para se chegar a locais inóspitos e de rara beleza em meio à natureza.

Em campeonatos, as regras do trekking podem se assemelhar às utilizadas em competições de rally de regularidade. Há um navegador que tem de guiar sua equipe, de acordo com um tempo pré-estabelecido, até a linha de chegada. Por ser um esporte acessível e fácil de praticar, basta caminhar, é comum encontrar famílias que participam de campeonatos.

É uma atividade que pode ser praticada por qualquer pessoa em qualquer idade (ressalvo àqueles que estão há muito tempo sedentários), o trekking é muito acessível do ponto de vista financeiro e muito seguro a nível físico.

Em qualquer lugar pode se praticar o trekking. Há belíssimos locais para a prática no Brasil, de norte a sul e de leste a oeste, é uma atividade sem fronteiras.

O trekking já virou moda! Para fugir do agito das grandes cidades ou somente para relaxar e curtir a natureza. Pessoas de todas as idades têm procurado lugares bonitos e exóticos cobertos de mata para caminhar com sua família e amigos. Veja aqui alguns cuidados que devem ser tomados.

Trek significa migrar. Possivelmente uma herança da colonização inglesa no mundo, principalmente África e América do Norte, onde os trekkers viajavam meses em suas carruagens a boi, ou mesmo a pé. Carregando todos os seus pertences de um lado para outro, muito parecido com os nômades do oriente.

Justamente por esta definição de migração, mudança, viajar, "carregar a casa" e que o termo trekking é empregado para esta atividade. Também há os termos backpacking e hiking, comumente utilizados na América. 
Como é uma atividade inerente ao homem não há um marco histórico do início desta atividade, mas com as conquistas de montanhas ao redor do mundo as práticas do trekking já poderiam ser sinônimas de aventura.

O trekking é uma atividade física, aeróbica, com marcada presença no conjunto muscular das pernas e quadril. Na tradução para o português a palavra trekking nos remete a caminhar, trilhar, andar. A mais remota e conhecida forma de deslocamento desde que o homem ascendeu à qualidade de bípede.

O caminhado em si não faz sentido a não ser que esteja acompanhada de alguma motivação, seja ela física ou psíquica. Podemos ir mais longe e dizer que o ato de caminhar também pode transcender estas questões e ser uma forma de relaxamento, prazer, convívio com a natureza ou consigo mesmo.

Sendo uma atividade que pode ser praticada por qualquer pessoa em qualquer idade (ressalvo feito àqueles que estão há muito tempo sedentários), o trekking é muito acessível do ponto de vista financeiro e muito seguro a nível físico.

Em qualquer lugar pode se praticar o trekking. Há belíssimos locais para a prática no Brasil, de norte a sul e de leste a oeste, é uma atividade sem fronteiras (ou quase, pois a expansão urbana e as cercas são limitadores perigosos!) que poderá ser praticada em qualquer época do ano sem a utilização de muitos acessórios.

Andar em trilhas, vencer desafios, ver belas paisagens. Procurando por essas sensações, muitas pessoas vêem se interessando em iniciar na prática do trekking. Por mais simples que pareça, porém, este esporte demanda também tempo para aprendizado. Por isso, estar atento e disposto a aprender com tudo é fundamental.

Uma das maneiras de você iniciar na prática do esporte é fazendo sua primeira trilha com uma agência especializada neste tipo de passeio. Apesar do custo, é essa a maneira mais correta e segura de você sentir o seu ritmo, as suas necessidades e as dificuldades de uma trilha. Mesmo contando com o auxílio dos guias, procure prestar atenção no caminho e nas soluções dadas aos problemas que surgirem. Essas informações serão muito úteis quando você for fazer uma trilha apenas com seus amigos.

Depois deste primeiro passo, procure fazer novamente a mesma trilha, acompanhado de um guia local. Busque o máximo possível de informações sobre 
o lugar, o tamanho da trilha, a dificuldade, etc. Lembre-se de que você está começando e deve, por isso mesmo, escolher um passeio já conhecido, para que possa se planejar melhor e executá-lo sem problemas.

Para competir -Outra forma de entender a dinâmica deste esporte é começar em competições do chamado trekking de regularidade. Há empresas organizando estas competições em vários estados brasileiros.

É importante que, desde a primeira trilha, você entenda a importância de planejar. Vejam quais serão as suas necessidades, faça uma lista dos equipamentos necessários, escolha um tênis ou bota confortáveis, a alimentação que será utilizada. Quando planeja, o trekker já está iniciando a aventura.

Nunca vá sozinho - A regra fundamental de segurança no trekking é: nunca vá sozinho fazer uma trilha. O número mínimo ideal de pessoas em um grupo é de três pessoas. Desta forma, você terá quem ajudá-lo e quem possa procurar ajuda caso encontre algum problema no meio da trilha.

Outro quesito importante para evitar que um passeio tenha um final pouco agradável é a humildade. Entendam os seus limites, vá com calma e não tente mostrar aos outros que pode fazer isso ou aquilo. Apenas perceba se pode e, se encontrar dificuldades, saiba pedir ajuda.

Tomando todos esses cuidados, você poderá começar a aproveitar os desafios e belezas das trilhas. E ser bem vindo ao mundo do trekking!

\subsection{7- O Rapel}

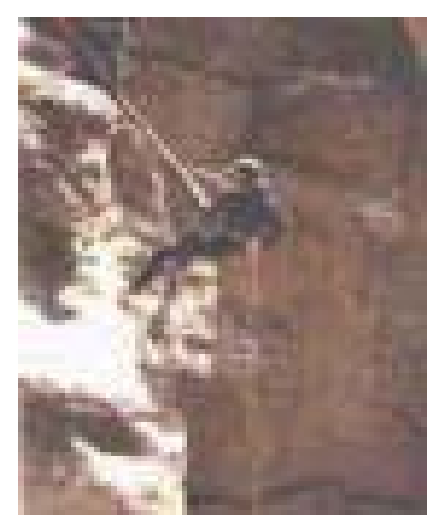

Figura5- Rapel

Fonte: Site <www.ecoviagem.com.br> 
O "rapel" é uma técnica montanhista para efetuar a descida, na qual o mesmo desliza de forma controlada por cordas ou cabos uma cadeirinha especial e alguns acessórios, tais como mosquetões, oito, etc, etc; vencendo obstáculos como cachoeiras (canyoning), paredões, abismos, pontes, declives (exploração de grutas e cavernas) e resgates que vem sendo muito praticado como esporte radical.

O rapel tem alguns estilos bem diferentes de ser praticado. Dê uma olhada abaixo e saiba um pouco mais sobre cada um deles.

Rapel em positivo - É realizado com o apoio dos pés na parede. É o mais normal e mais conhecido entre os praticantes.

Rapel em negativo - Neste caso é feito sem o apoio dos pés. O praticante lança-se no vácuo e desce em queda livre. A sensação de vazio é alucinante e o clímax deste estilo é o início, onde às vezes falta coragem para se jogar.

Rapel guiado - Normalmente usado em cachoeiras e quedas d'água, onde é necessário fazer um desvio diagonal da trajetória para evitar fortes torrentes.

Rapel fracionado - É dividido em vários rapéis menores para encontrar um caminho mais seguro.

Antes de sair para a prática do rapel confira um a um todo o material. Mesmo que você saiba que está todo OK. É sempre bom estar prevenido contra tudo.

Esteja sempre atento aos comentários sobre o rapel de cada via. Sempre que possível, leve consigo duas cordas, pois rapelar do meio de certas vias, não é trivial. Cogite abandonar algum material se necessário.

Dê preferência aos equipamentos que tenham os selos do UIAA e CE, e que tenham a sua capacidade de peso suportada gravada no próprio aparelho. Estes dois selos garantem que todos são testados e aprovados.

Leia o manual do produto que você comprar. Confira os pesos suportados, mínimos e máximos. Verifique cada detalhe do produto. 
Existem muitos lugares catalogados e não catalogados, de diversos tipos como: (Prédios, Cachoeiras, Montanhas, Pedreiras, Fendas, Poços, Pontes, Torres, Cavernas, Gargantas, Penhascos, Abismos, etc.)

Os mais famosos e tradicionais lugares são as "Cachoeiras - (Canyoning), Pontes e Cavernas", por serem lugares considerados turísticos, mas para quem já rapela e possui uma boa experiência, os lugares prediletos são os prédios, de preferência os que estão abandonados.

\section{Mas porque os prédios?}

Bom, pode não ser a opinião de muitos Rapeleiros novatos e até mesmo alguns veteranos, mas um bom rapeleiro prefere um prédio abandonado, principalmente se ele domina as técnicas de Ações-Táticas, e Resgate em Altura.

\section{4- Regras básicas e precauções contra acidentes}

1- O risco não deve ser temido, mas identificado para ser controlado.

2- Regra básica: tenha consciência de que acidentes podem ocorrer!

3- Consciente da regra saiba que você pode evitá-los!

4- Não aja de maneira impulsiva e precipitada. Atos e comportamentos de risco podem provocar acidentes.

5- Procure empresas e equipes de apoio qualificadas.

6- Procure conhecer as características da atividade e dos equipamentos para evitar o manuseio errado e o surgimento de falhas mecânicas.

7. Faça um plano claro, defina os procedimentos básicos e os riscos que pode enfrentar. 


\section{Turismo de Aventura no DF e entorno - Potencialidades}

Todo o território do Distrito Federal, exceto áreas urbanas, constitui desde janeiro de 2002 áreas protegidas por lei -uma grande APA do Planalto Central envolve parques, reservas, floresta nacional, estações ecológicas, outras APAS, ARIES, RPPNS etc. Os roteiros de turismo ecológico a partir de Brasília são facilitados por esta situação privilegiada. A natureza também ajuda: localizada acima de mil metros acima do nível do mar (cota do Lago Paranoá), no coração da América do Sul, Brasília está num platô de onde nascem as águas que formam todas as grandes bacias hidrográficas brasileiras. Da Estação Ecológica de Águas Emendadas, no DF, nascem as águas que correm tanto para o norte (bacia do Tocantins) quanto para o sul (bacia do Prata). Ali perto, nas nascentes do rio Preto, nascem as águas que formarão a bacia do rio São Francisco, que corre para leste e nordeste, até cair no Atlântico. Sem praias, o Distrito Federal dispõe de cachoeiras, córregos, rios, lagos e lagoas. Em sua volta há cidades históricas, refúgios naturais, reservas, monumentos naturais e principalmente as formações do cerrado, o tipo de vegetação que recobre todo o centro-oeste brasileiro.

A cidade em si é uma atração cheia de verde. Nos últimos anos, tornou-se vítima do crescimento populacional acelerado e do impacto da ocupação desordenada do solo sobre os recursos hídricos. Inaugurada em 21 de abril de 1960, a nova capital foi planejada para ter 500 mil habitantes em 40 anos - mas chegou ao ano 2000 com 2,1 milhões de habitantes dentro do Distrito Federal e outros 900 mil no Entorno, região formada por municípios do Estado de Goiás.

\section{1- Formosa}

Além de hotéis-fazenda, lagoas e alguns restaurantes de comida caseira típica, Formosa entra no roteiro de turismo ecológico com o cartão postal do Parque Municipal de Itiquira, onde está a maior queda d'água do Centro-Oeste, com 169 metros de altura. Antigo arraial dos Couros nasceu como um entreposto das tropas de mulas que se cruzavam nesta região do Planalto Central. De um 
lado as caravanas transportando ouro, vindas das minas do norte (Cavalcante, São Félix etc) ou do sul (Vilas Boas de Goiás, Meia-Ponte etc). Procuravam escapulir da vigilância dos cobradores de impostos desviando-se do caminho oficial para a província de São Paulo (sudeste de Goiás) para tentar os sertões da Bahia, de onde esperavam atingir o litoral. De outro, vindo dos campos baianos chegava o gado que abastecia as populações mineiras que continuaram crescendo por décadas, desde o descobrimento em 1725 até o esgotamento do ouro. Com o ciclo da pecuária que se seguiria à longa recessão, a Vila de Nossa Senhora dos Couros prosperou até ganhar o nome atual de Formosa, município goiano a 80 km do centro de Brasília.

\section{2- Cristalina}

Situada a $100 \mathrm{~km}$ da rodoviária de Brasília, na Serra dos Cristais, é uma cidade a 1.300 metros de altitude que atrái milhares de visitantes por causa de seu comércio de cristais de quartzo (e outras pedras semipreciosas) e pelas belezas naturais em volta, com riachos, cachoeiras (Lajes, Dourada etc), formações rochosas (como a Pedra do Chapéu) e reservas particulares do patrimônio natural (como a RPPN Linda Serra dos Topázios, a $6 \mathrm{~km}$ da cidade).

Antigamente foi um importante centro minerador de cristais, o que deixou muitas áreas degradadas, com buracos e valas a céu aberto provocando erosão. Chegou a ser o principal fornecedor à indústria eletrônica americana na II Guerra Mundial. Enfrentou a decadência com a concorrência do cristal sintético, até se recuperar a partir da inauguração da nova capital federal em 1960, já que se situa no entroncamento de rodovias ligando Brasília a Belo Horizonte.

\section{3- Cachoeiras}




\section{Itiquira}

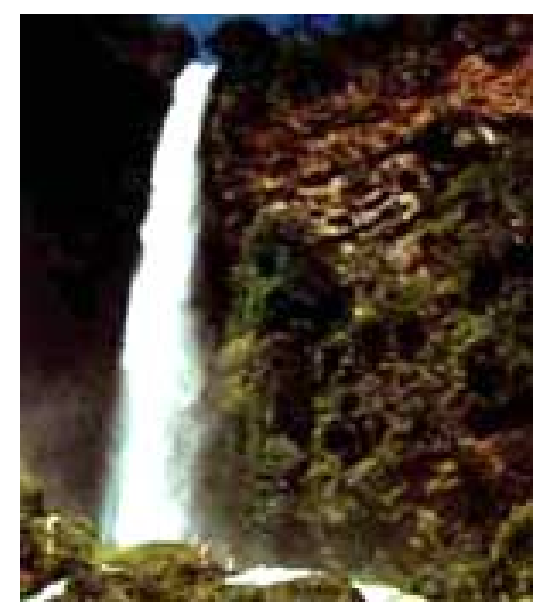

Figura6- Itiquira

Fonte: Site <www.eco.tur.br>

A segunda maior cachoeira do Brasil em altura $(169 \mathrm{~m})$, situa-se nas encostas do Planalto Central, no município de Formosa (GO), podendo ser alcançada por estrada de asfalto (115 km da rodoviária de Brasília). Ao pé da cachoeira, o espetáculo da água que mal consegue chegar ao solo, devido à altura, é dos mais bonitos - principalmente quando há muita luz do sol para formar arco-íris em volta. Está protegida por uma unidade de conservação local - o Parque Municipal de Itiquira. Sua administração é descentralizada através de uma fundação. Passeio ideal para se fazer logo no início da manhã. Além da cachoeira e do rio Itiquira, há uma trilha toda íngreme, levando por entre matas de encostas até o alto do penhasco, permitindo uma vista privilegiada. Quem quiser se hospedar próximo ao parque de Itiquira pode procurar a Estância Águas do Itiquira, pelo telefone (61) 225-6601 ou fax (61) 225-2507.

\section{Dois Irmãos}

Trata-se de um conjunto de 30 quedas d'água e poços, situados no ribeirão Dois Irmãos, dentro da APA de Cafuringa, ao norte do Distrito Federal. Atualmente encontra-se dentro de uma posse particular, denominada Fazenda Imperial, onde se aceitam visitantes em grupos previamente agendados. 
Situa-se em borda de chapada, conta com vegetação relativamente bem preservada, inclusive matas de galeria típicas do cerrado. É um dos mais lindos pontos da chapada da Contagem, que ficou preservado por não servir para exploração agropecuária.

Para chegar, a partir de Brazlândia (DF) toma-se a BR-180 e depois vira-se à direita em estrada de terra (DF-205). Logo após a ponte do ribeirão Amador, entra-se à direita na fazenda do córrego Dois Irmãos, onde está o empreendimento Imperial.

\section{Topázios}

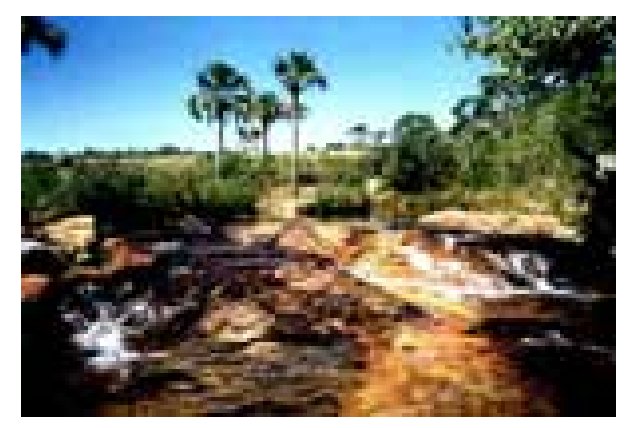

Figura7- Rio topázios

Fonte: Site <www.eco.tur.br>

As cachoeiras do rio Topázio, no município de Cristalina (GO), são uma série de corredeiras, quedas d'água, pedreiras e poços bastante preservados, pelo fato de estarem dentro de uma unidade de conservação sujeita à fiscalização do Ibama. Trata-se na realidade de área da Reserva Particular do Patrimônio Natural (RPPN) Linda Serra dos Topázios, uma das mais bem conservadas do cerrado.

Nascendo no alto da chapada da Serra dos Cristais, o rio Topázio junta-se na parte mais baixa da reserva ao ribeirão Areião, dentro de um cânion cercado de paredões de pedra de ambos os lados. Além dos rios, a grande atração em volta é o próprio cerrado, em sua forma original. Mesmo assim, vem sofrendo as conseqüências da agricultura mecanizada de soja nas proximidades, o que leva agrotóxico pulverizado de aviõezinhos até a área da reserva. O turismo predatório ainda acontece à margem direita, fora da reserva, mas em escala bem menor do que antigamente. 
Para se chegar até o rio Topázio, saindo de Brasília, deve-se tomar a BR040 até Cristalina (GO), virando-se à direita no anel rodoviário e seguindo pela BR-050 por alguns minutos até que, passando três quebra-molas, entra-se à direita numa estrada de terra, onde há placas de sinalização. Rodam-se $7 \mathrm{~km}$ na terra, em estrada que depende do regime de chuvas, para se chegar até o portão de entrada da reserva. Paga-se uma pequena taxa para passar o dia. Antes de visitar a RPPN recomenda-se fazer contato pelo telefone (61)504-0149.

Indaiá

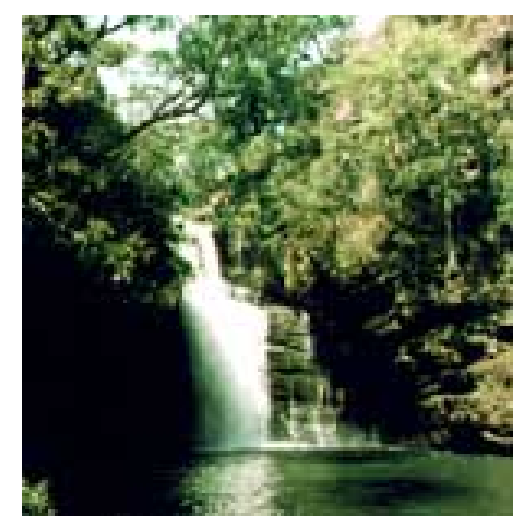

Figura8- Indaiá

Fonte: Site <www.eco.tur.br $>$

Uma série de cachoeiras, sendo a maior com 30 metros de altura, situadas no rio Itiquira, no alto da chapada em cuja borda está o Salto de Itiquira, com 169 metros. Leva este nome devido à ocorrência da palmeira indaiá em toda a área, que deu nome também à água mineral da fazenda onde se situam as cachoeiras de Indaiá.

A partir de Brasília deve-se tomar a rodovia BR-020 rumo a Formosa, entrando-se antes daquela cidade, à esquerda, na rodovia GO-118, no sentido de São Gabriel (GO). Rodam-se 10km, até um trevo, onde se deve virar à direita até a primeira curva, onde novamente se vira à esquerda, na placa do Camping Club do Brasil (CCB). Seguindo direto chega-se à entrada da Fazenda Indaiá, onde se paga uma pequena taxa de visitação. 


\section{Mumunhas}

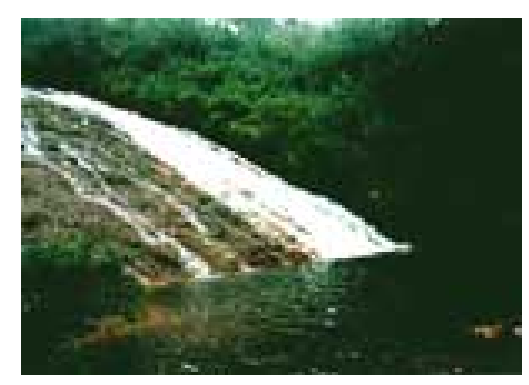

Figura9- Mumunhas

Fonte: Site <www.eco.tur.br>

Uma das mais conhecidas de Brasília, Mumunhas é na realidade uma série de cachoeiras no córrego Cupins, dentro da APA de Cafuringa, ao norte do Distrito Federal. Até a década de 1980 foi explorado excessivamente pelo turismo, o que provocou a degradação da mata e de algumas nascentes, devido às estradas de carros e conseqüente erosão. Situa-se dentro de terras reivindicadas por particulares, que arrendaram a área para religiosas da ordem denominada Columba. Os arrendatários fecharam a área para recuperação, proibindo temporariamente a entrada.Trata-se de um monumento natural, declarado em lei regulamentada pelo Decreto Distrital 17.430/96, cuja exploração por parte do turismo ecológico depende agora de plano de manejo e supervisão governamental.

Chega-se até Mumunhas, partindo do Alto do Colorado, pela DF-001 (Lago Oeste), até o trevo com a DF-220. Vira-se à direita nesta estrada de terra até as proximidades das antenas da Radiobras, em frente às quais está a porteira que dá acesso ao córrego.

\section{Paranoazinho}

São duas quedas d'água, formadas no córrego Paranoazinho, situado próximo à DF-150 (região do Colorado), bastante utilizadas para lazer da 
comunidade local. É um vale, com um pequeno poço para banho, que já sofreu o impacto da presença humana.

O córrego nasce na Chapada da Contagem, próximo à DF-001, sendo área de captação por parte da Companhia de Água e Esgoto de Brasília (Caesb). Após as duas quedas d'água, o córrego cai no ribeirão Sobradinho.

Para chegar, a partir do Alto do Colorado, toma-se a DF-150 até o balão do bairro Grande Colorado, onde se deve estacionar o carro em vagas do comércio. Dali segue-se à pé, descendo o vale rumo ao córrego Paranoazinho.

\section{Tororó}

Tororó, situada no córrego Caxeta, é uma cachoeira de queda livre com aproximadamente doze metros de altura, com água suficiente para provocar efeitos especiais quando o vento está forte. Raso, o poço é rodeado por uma mata de galeria que vem sendo degradada pela abertura de trilhas, principalmente por parte de visitantes que querem ter acesso aos paredões de pedra muito procurados para a prática de rapel.

As nascentes do rio foram prejudicadas pela presença de condomínios (São Francisco 1, 2 e 3, Flamboyant, Chapéu de Pedra e outros) e por plantações de soja da antiga Fazenda Santa Mônica.

A partir do Lago Sul, toma-se a saída para a Escola Fazendária na QI 23, passando diante do Jardim Botânico, até o trevo de onde se acessa a DF-140. No balão seguinte, onde está a saída para Unaí (MG), basta seguir adiante na própria DF-140, até o quilômetro seis, numa curva, de onde se deve entrar numa estrada de terra à direita, que leva até a o início da trilha cujo final é o monumento natural. Tororó encontra-se dentro de terra particular, mas a entrada ainda não é cobrada (paga-se apenas uma pequena taxa pelo estacionamento). 


\section{Poço Azul}

A mais conhecida cachoeira e poço de Brasília desde os anos 1970 situamse no rio da Palma, na APA de Cafuringa (norte do Distrito Federal). Na década de 1980 o turismo sem controle causou degradação ambiental. Nos anos90, quando foi declarado monumento natural, o Poço Azul passou a ser um local de visitação controlada, onde as pessoas que têm o domínio de posse na área cobram uma pequena taxa e cuidam da preservação.A área foi desmatada por grileiros, cujo intento de construir o condomínio Morado dos Pássaros foi impedido pela Secretaria do Meio Ambiente em 1996, pois prejudicaria todas as nascentes do rio da Palma e, portanto o monumento natural. Houve depois uma invasão de sem-terras, que foi removida para o assentamento "26 de setembro", dentro da unidade de conservação da Floresta Nacional de Brasília, criada em 1999.

Lugar bastante bonito, com corredeiras, trechos de rio calmo e ao final um poço ideal para banho, mas bastante perigoso, devido à profundidade e presença de pedras.

Chega-se até o Poço Azul, partindo do Alto do Colorado, pela DF-001 (Lago Oeste), até o trevo com a DF-220. Vira-se à direita nesta estrada de terra, onde logo depois se avistam placas de sinalização, nas proximidades de alguns eucaliptos. Seguindo-se as placas chega-se até um portão, junto à sede da fazenda, podendo descer de carro até mais perto do rio.

\section{4- Estação ecológica de águas emendadas}

Sob responsabilidade da Secretaria do Meio Ambiente e dos Recursos Hídricos (SEMARH), localiza-se a $50 \mathrm{~km}$ da rodoviária, a nordeste de Brasília, fazendo limite com Planaltina-GO (norte) e Planaltina-DF (sul), com uma área de 10 mil 547 hectares. 
É uma unidade de conservação de proteção integral destinada à proteção do ambiente natural, realização de pesquisas básica e aplicada em ecologia e à educação conservacionista. Pelo seu excelente estado de conservação dos ecossistemas foi declarada em 1992 pela Unesco como uma das áreas que compõem a área nuclear da Reserva da Biosfera do Cerrado - fase I. Vegetação: cerradão, cerrado stricto sensu, campo cerrado, capo sujo, campo limpo, mata de galeria alagada e não alagada, veredas, campo úmido e campo de murundus.

Grande número de animais do cerrado se abrigam e se alimentam em Águas Emendadas, podendo ainda encontrar alguns mamíferos ameaçados de extinção tais como o lobo-guará, veado-campeiro, tatu-canastra e o tamanduá-bandeira. Além disso, diversas aves podem ser observadas com freqüência tais como tucanos, papagaios, carcarás e seriemas.

Ocorre nessa região o extraordinário fenômeno hidrográfico: o nascimento de duas grandes bacias continentais, vertendo de um mesmo ponto. Em uma vereda de aproximadamente $6 \mathrm{~km}$ de extensão afloram dois córregos em lados opostos: o córrego Vereda Grande corre para o norte, encontra o rio Maranhão que vai alimentar o caudaloso rio Tocantins. O córrego Brejinho corre para o sul, engrossa o córrego Fumal e logo após, para o rio São Bartolomeu, depois para o Corumbá, desaguando no Paranaíba e formando então o rio Paraná.

Não é permitida visitação pública, apenas a permanência de pesquisadores e atividades de cunho educacional. Dispõe de prédios para a Administração (fiscalização e depósito de materiais) e Centro de Informação Ambiental (auditório) -Foi criado pela Lei Federal no 6902/81 e decretos distritais 771/68, 6004/81 e 11137/88. 


\section{5- Parque Nacional de Brasília - Água mineral}

A cidade de Brasília é um símbolo de progresso e modernidade. Mas a apenas $10 \mathrm{~km}$ da capital nacional está uma importante área de preservação ambiental: o Parque Nacional de Brasília. A área preserva uma grande quantidade de espécies animais e vegetais típicas do cerrado, um dos ecossistemas mais ameaçados do país. Lá também nascem os principais rios que abastecem as cidades da região. Além disso, o parque é a principal área de lazer do Distrito Federal.

O Parque Nacional de Brasília surgiu no contexto da construção da cidade de Brasília como nova capital do Brasil, na década de 60 . Os 30.000 hectares do parque, criado em 1961, protegem uma importante amostra do cerrado.

Está localizado no Distrito Federal, a $10 \mathrm{~km}$ da rodoviária de Brasília. Para chegar até lá, a partir do Plano-Piloto de Brasília, seguir pela Estrada Parque Indústria e Abastecimento (EPIA - BR-040), entre a Rodoferroviária e o Balão do Torto, passando pelo Setor Militar Urbano, $9 \mathrm{~km}$, com acesso pelo Eixo Monumental Oeste.

O clima da região é tropical, semi-úmido, com temperatura média anual de $21^{\circ} \mathrm{C}$. O parque pode ser visitado o ano todo.

A área abriga as nascentes dos rios Torto e Bananal que formam a Barragem de Santa Maria, que abastece o Plano-Piloto com água potável. Mas apesar disso, grande parte da água corre em lençóis profundos, deixando o local seco durante quatro meses por ano.

É uma importante reserva de cerrado, com mais de 700 espécies de vegetais e outras centenas de animais. Dentre as plantas destacam-se o jacarandá-domato, o pequizeiro, o buriti, a guariroba e os ipês roxo e amarelo. Refúgio de diversos animais, o parque abriga espécies ameaçadas de extinção como o loboguará, o tatu-bola e o tamanduá-bandeira. Além destes podem ainda ser encontrados veados, sagüis, tapetis, cachorros-do-mato, emas e tucanos.

O parque é uma das principais áreas de lazer do Distrito Federal, sendo que a maior parte dos visitantes procura refrescar-se em uma de suas duas piscinas. Existem também duas trilhas de pequena dificuldade: a da Capivara com duração 
de 20 minutos e a do Cristal Água cujo trajeto pode ser percorrido em 1 hora. O Centro de Visitantes oferece caminhadas programadas.

Sua supervisão está a cargo do Ibama, mantendo o Parque aberto das 8 às 16h. Tel: (61) 233-4055

\section{6- Empreendimentos entorno de Brasília}

O modo de vida do brasiliense passa por transformações. Fins de semana no litoral são substituídos por visitas ás chácaras de amigos. Pantanal e floresta Amazônica dão lugar à trilha, grutas e cachoeiras do Planalto Central, e assim por diante...Vai surgindo ai o nicho de mercado que pode alavancar a produção rural e a ela agregar novos produtos e serviços. Eis algumas propriedades para visitação:

\section{- Chapada Imperial}

Distância da rodoviária: 52,2Km. DF 220 Km 09.

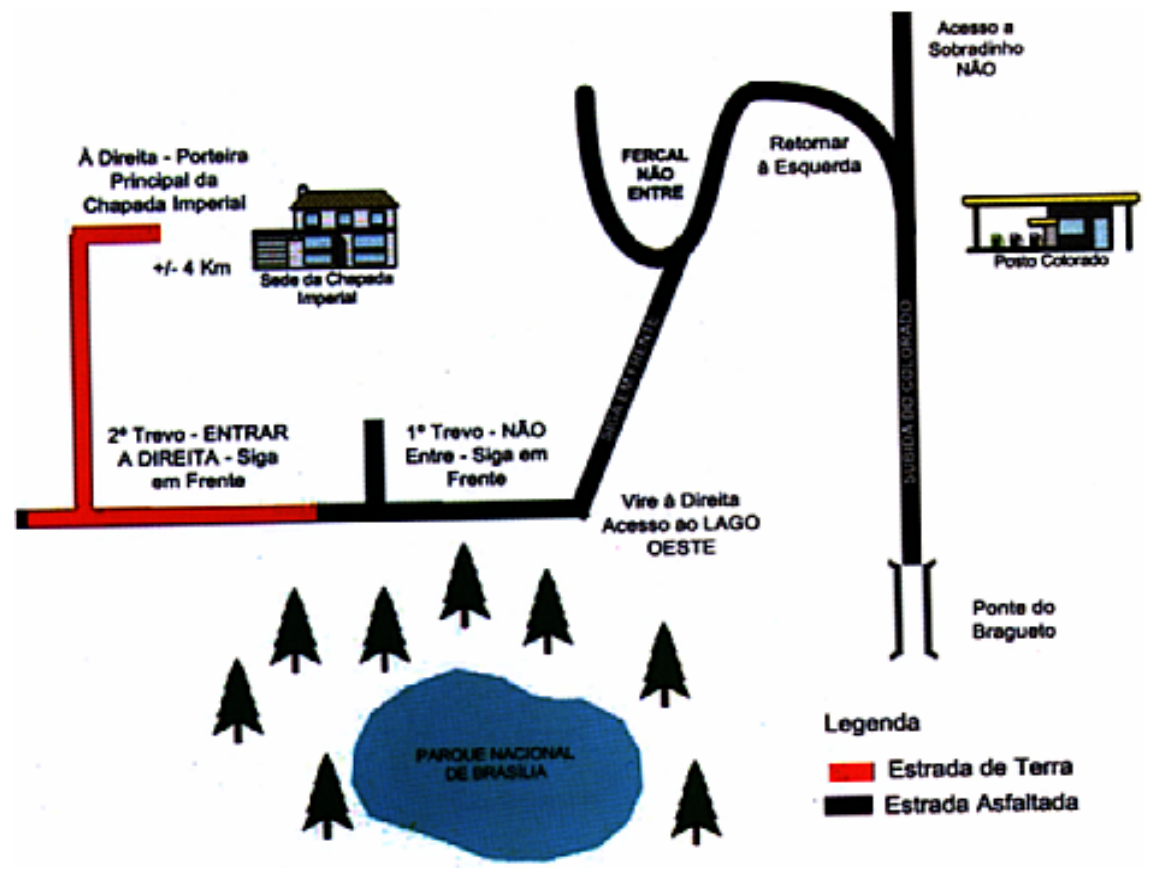

Figura10- Chapada Imperial Fonte: SEBRAE, 2003. 
Tem como atrativos: Educação ambiental. Animais silvestres (graciosamente). Horta orgânica, produção de ervas medicinais, cavalgadas. Rios, ribeirões, córregos, nascentes, montanhas, elevações rochosas, trilhas ecológicas. Esse empreendimento possui patrimônio de valor histórico, cultural e natural. 33 cachoeiras. Maior reserva particular do DF. Ponto mais alto do DF - 1347 metros. Única propriedade com 95\% de área preservada. Trilhas para jeep e mountain bike. Telefone para contato: 9984-4437 / e-mail: chapadaimperial@loreno.net (SEBRAE, 2003)

- Fazenda Monjolo

Distância da rodoviária: 45 Km. DF 205 Km 70.

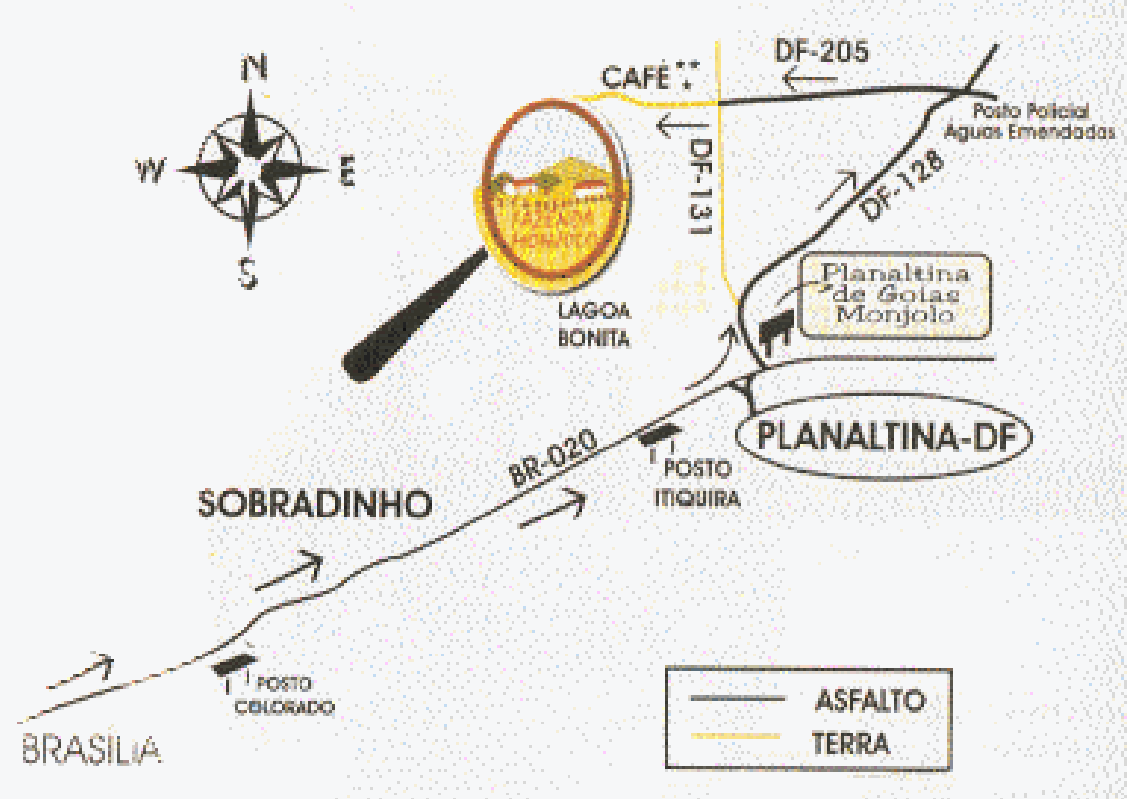

Figura11- Fazenda Monjolo Fonte: SEBRAE, 2003.

Tem como atrativos: Produção de doces e lou geléia. Apanhar frutos no pé. Rios, ribeirões, córregos, cachoeiras, lagos, lagoas naturais, trilhas ecológicas. Telefones para contato: 389-2334 / 9981-9086 / Fax - 366-2554. (SEBRAE, 2003) 
- $\quad$ Agroturismo Buriti Alegre

Distância da rodoviária: 31,4 Km. DF 001 Km 42,5.

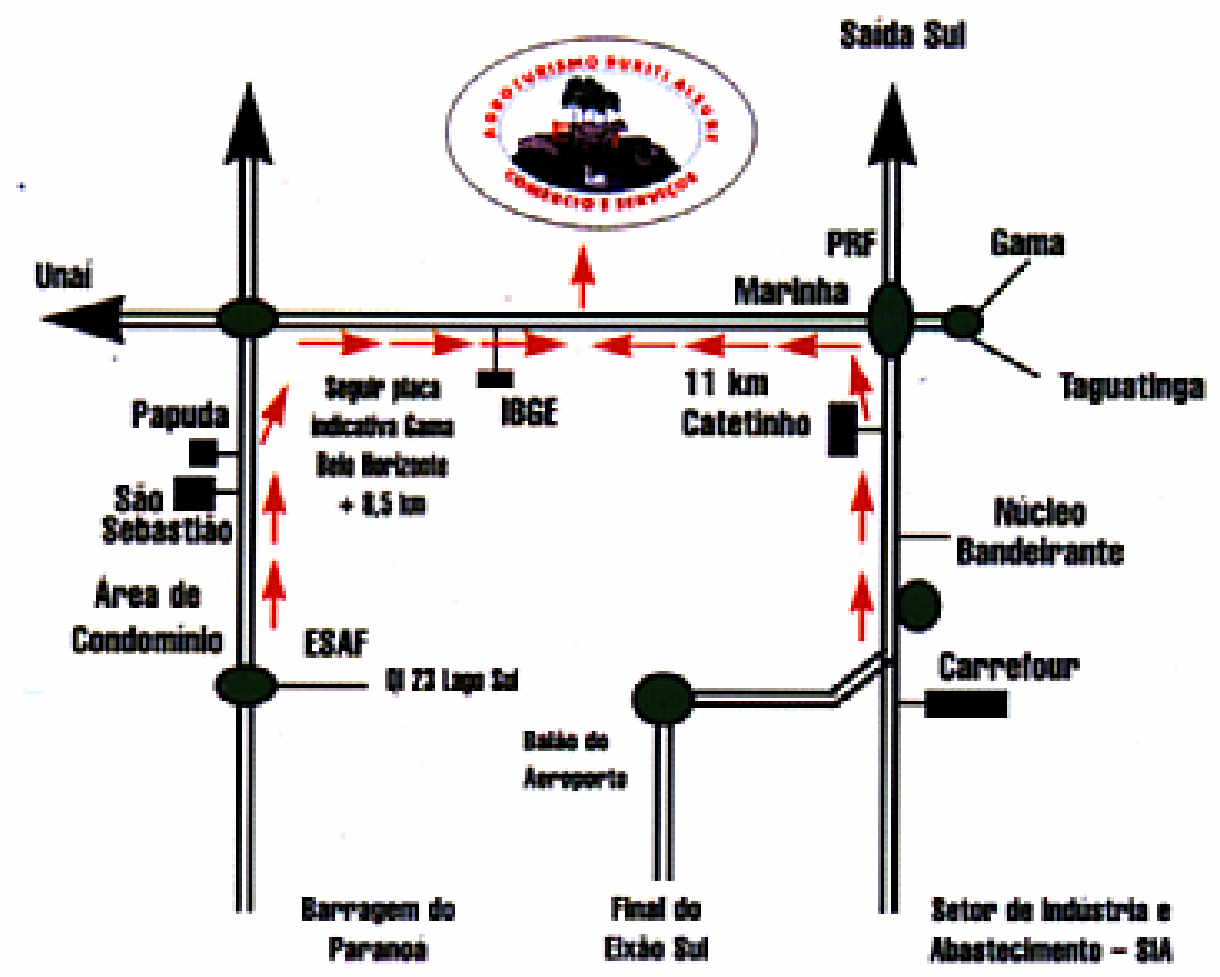

Figura12- Buriti alegre

Fonte: SEBRAE, 2003.

Tem como atrativos: Pesque-pague, disponibiliza ao pescador serviço de limpeza de peixe, vara, linha, anzol e iscas. Criação de bovinos, eqüinos, suínos, galinhas, marrecos, patos e animais silvestres. Possui horta orgânica, árvores frutíferas, pomar e agroindústria, além de atrativos como encilhar animais, colheita na horta, passeios a cavalo, nascentes, açudes artificiais, reserva florestal, e trilhas ecológicas. Telefones para contato: 500-5069 / 501-3355. (SEBRAE, 2003) 
- Irmão Sol

Distância da rodoviária: $24,7 \mathrm{Km}$. Núcleo rural lago oeste, rua 05 chácara 60c.

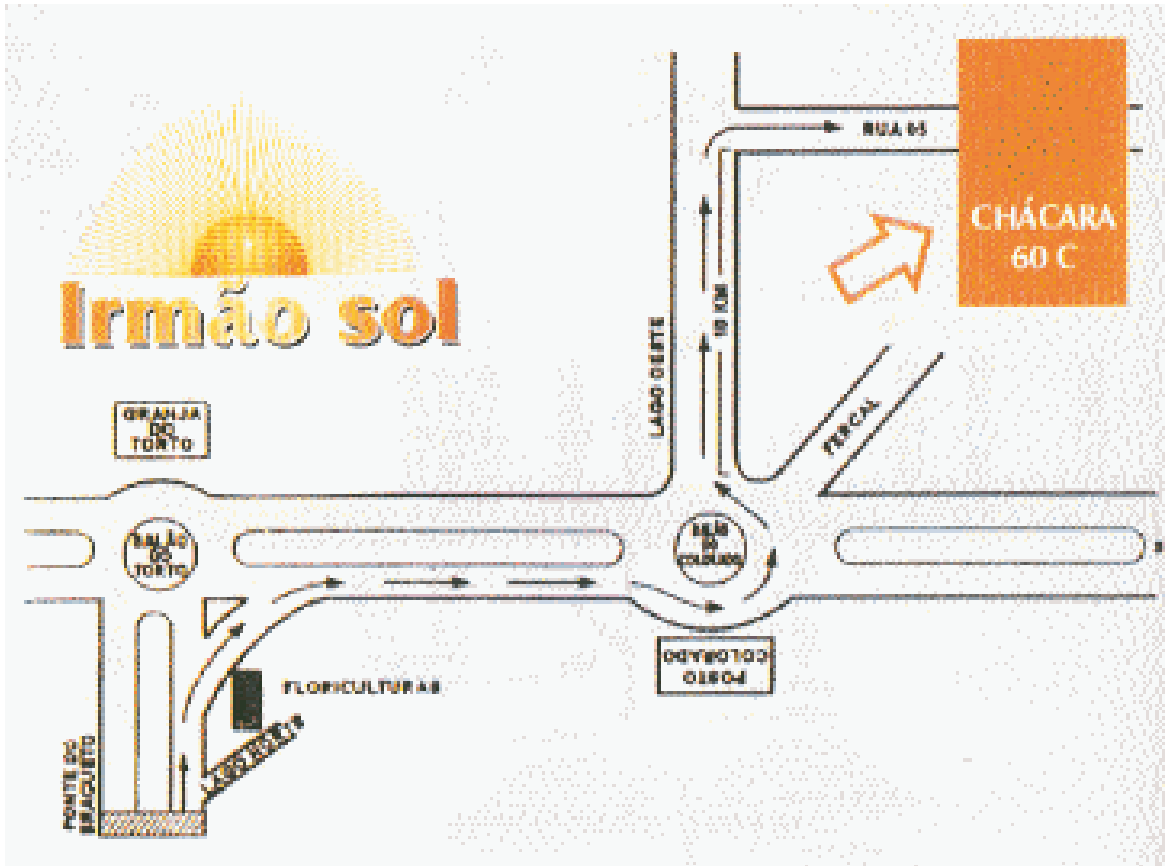

Figura13- Irmão Sol

Fonte: SEBRAE, 2003.

Tem como atrativos: Horta orgânica, produção de ervas medicinais, viveiro de plantas ornamentais. Produção de doces e/ou geléia. Apanhar frutas no pé, colheita na horta, trilhas para caminhadas. Telefones para contato: 478-1102 / 99715309. (SEBRAE, 2003) 


\section{- Agroturismo florida}

Distância da rodoviária: 47 Km / DF 130 Km 16, área isolada 03. Colônia Agrícola rajadinha. Planaltina - D.F

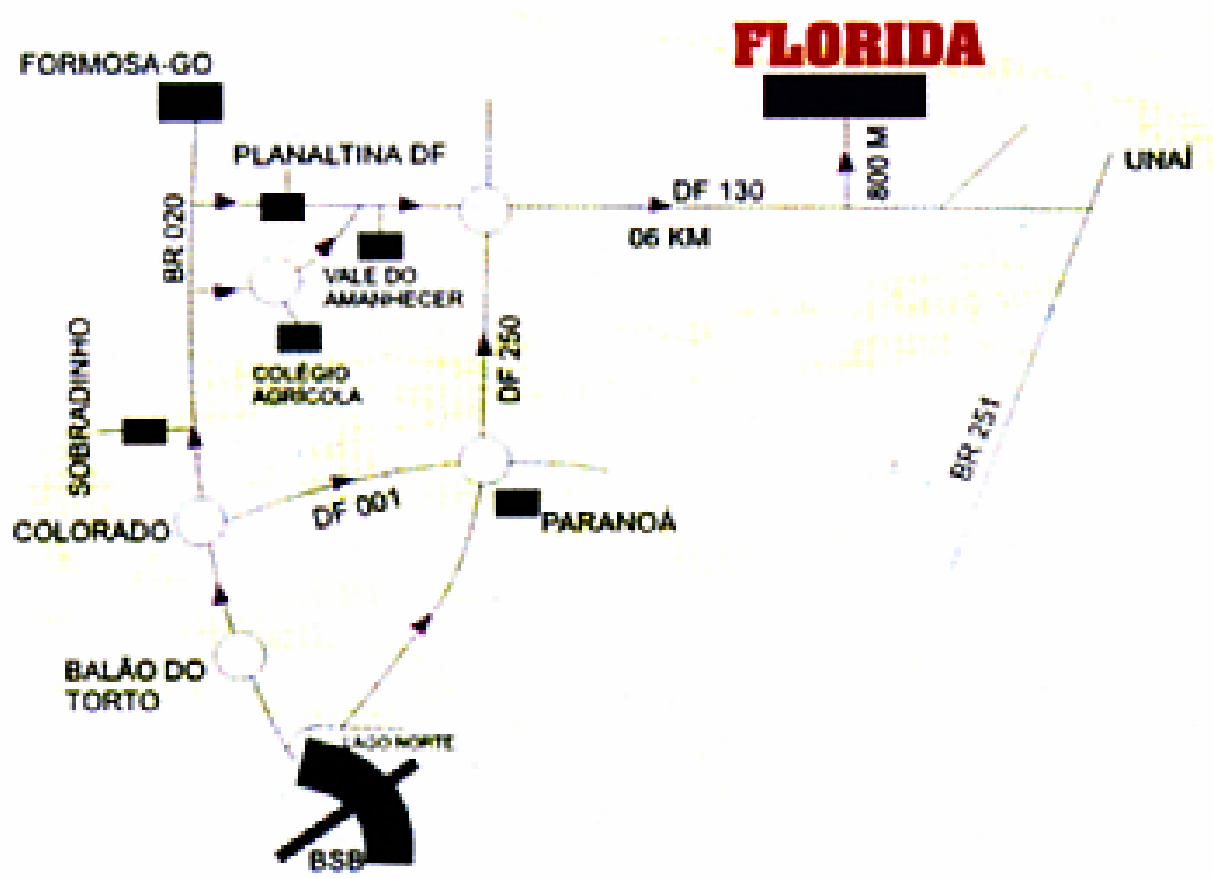

Figura14- Agroturismo Florida Fonte: SEBRAE, 2003.

Tem como atrativos: Possui pomar. Beneficiamento de leite. Córregos, nascentes, reserva florestal, trilhas ecológicas. Visitas á fábricas de alimentos artesanais. Açudes com local para banho. Passeio de Bugre e museu de leite. Telefones para contato: 500-0003 / Fax: 501-1993 (SEBRAE, 2003) 
- Sítio dos Girassóis

Distância da rodoviária: 32 Km. DF 140 Km 7,5 chácara 89 (estrada do Tororó)

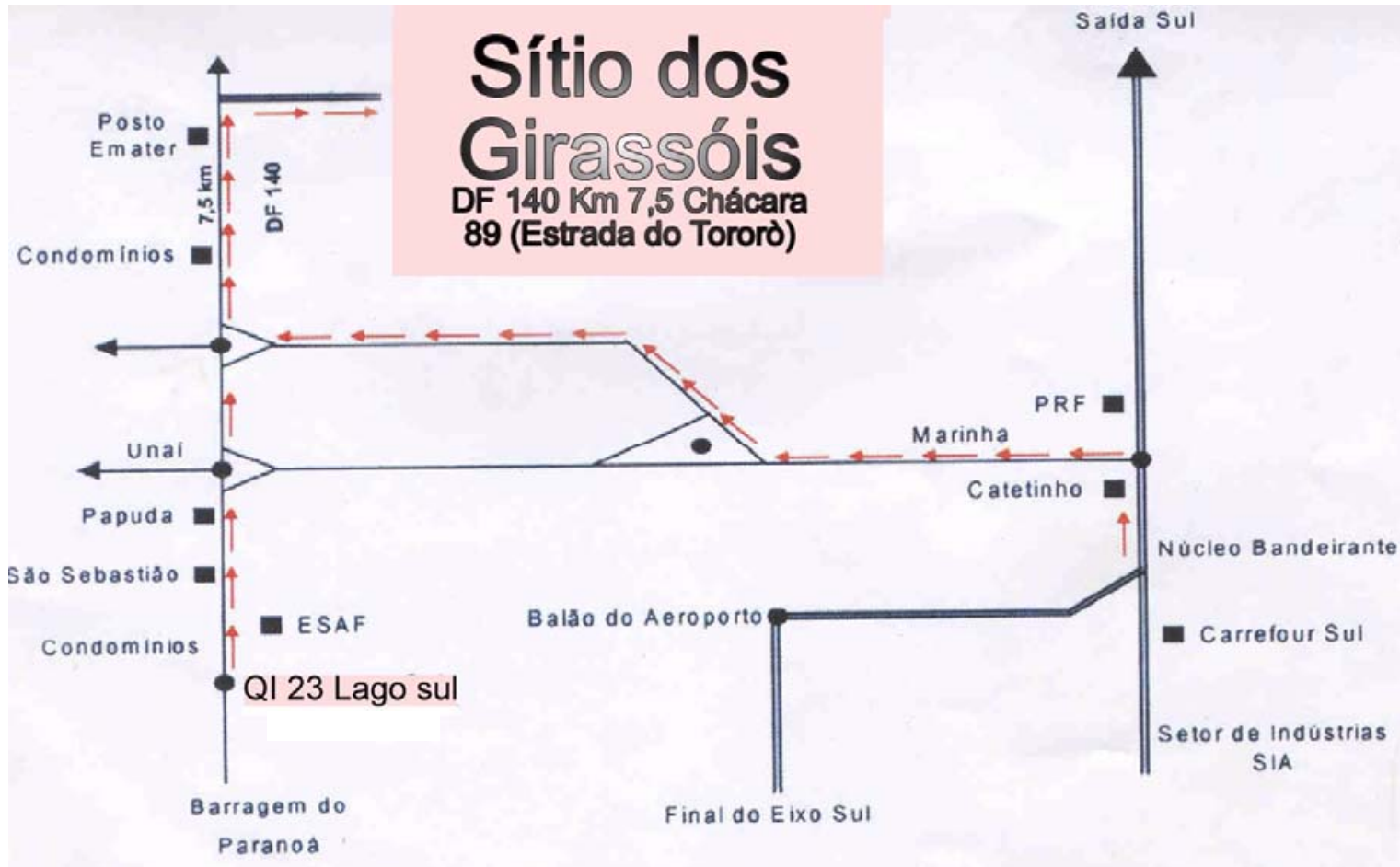

Figura15- Sítio dos Girassóis

Fonte: SEBRAE, 2003.

Tem como atrativos: Possui horta convencional e pomar. Criação de galinhas e codornas. Tem para o lazer: Piscina, sauna, churrasqueira, quadra de vôlei, tênis e futebol. Oferecemos acomodações e serviços de buffet para eventos, confraternizações, festas, retiros, lua de mel, etc... Breve terá trilha até a cachoeira do tororó. (Telefones para contato: 567-5469 / 934-2176) (SEBRAE, 2003). 
- Águas Correntes Saia Velha

Distância da rodoviária: 37 Km. BR 040 Km 05, esquerda 6 Km.

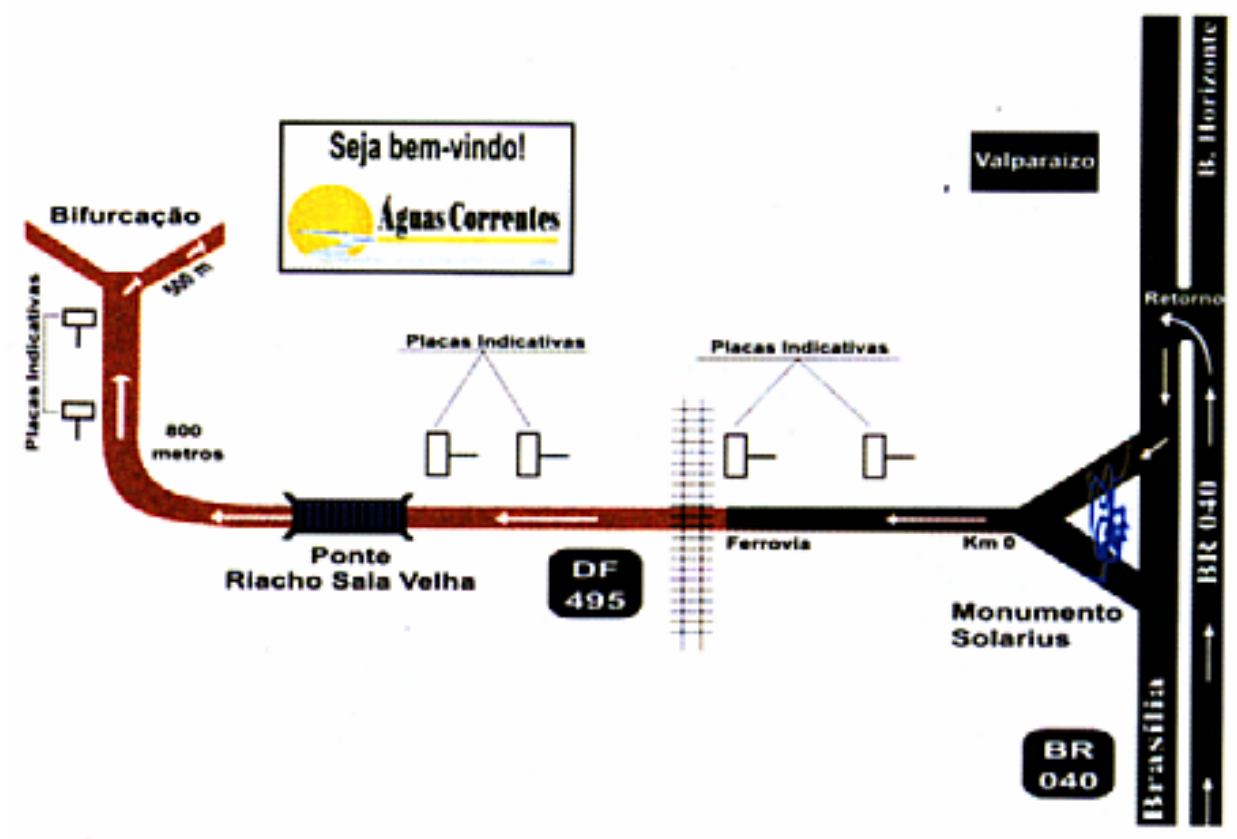

Figura16- Saia Velha

Fonte: SEBRAE, 2003.

Tem como atrativos: Oferece serviços de pescaria, com opção de compra e preparo do peixe para comer na hora ou levar para casa. Criação de piscicultura e pecuária. Passeios a cavalo, rios, cachoeiras, nascentes, reserva florestal. Esse empreendimento possui patrimônio de valor histórico e cultural. Telefones para contato: 3032-8080 / 242-1624. (SEBRAE, 2003). 
- Hotel Fazenda Cabugi

Distância da rodoviária: $150 \mathrm{Km}$. Rod. GO 139, KM 10. Próximo ao distrito olhos d'água. Alexânia - GO.

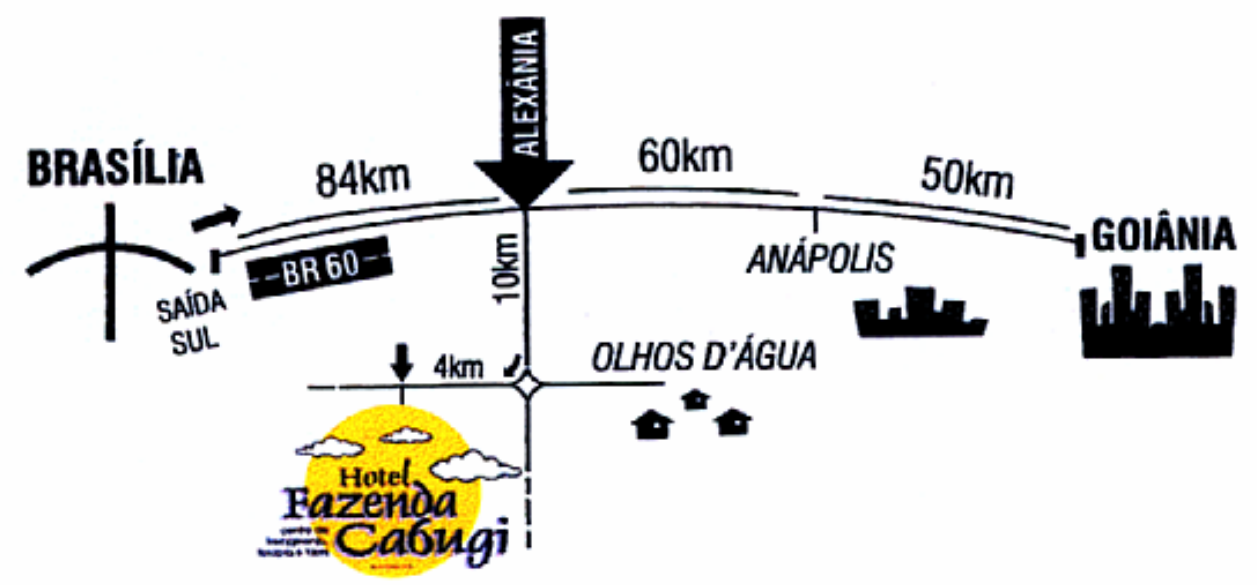

Figura17- Hotel Fazenda Cabugi Fonte: SEBRAE, 2003.

Tem como atrativos: Criação de bovinos, suínos, eqüinos, galinhas, patos, coelhos, etc. Animais silvestres. Horta orgânica, viveiro de mudas para reflorestamento e pomar. Apanhar frutas no pé, passeios de charrete, cavalgadas, passeios com pôneis. Rios, ribeirões, córregos, nascentes, açudes artificiais, reserva floresta e trilhas ecológicas. Telefones para contato: 502-8550 / Fax 336-9066. (SEBRAE, 2003) 


\section{Considerações Finais}

A realidade para Brasília, é que as cidades-satélites continuam avançando desordenadamente em torno do Plano Piloto. A solidão dói em suas avenidas largas, sem esquinas. A secura chega a índices de deserto. Não bastasse o único lago, o Paranoá, ser artificial, os brasilienses inventaram uma piscina com ondas para imitar o mar. No Clube do Congresso, criaram uma praia de mentirinha -com areia e palmeiras. Além de tudo, Brasília é olhada pelo resto do país como a cortesã do poder. Só quem consegue abstrair a intimidade desta jovem senhora com os burocratas vê Brasília com vida própria. Estende o olhar até os horizontes infinitos, sempre em "close", através de um céu límpido e azul. Em meio a obras de arte suavemente pousadas no Planalto, Brasília se impõe, pedra rara em pleno cerrado.

O ritmo alucinante das cidades tem gerado nas pessoas a necessidade de buscar ambientes diferentes e, principalmente, o contrato com a natureza.O que essas pessoas desejam é melhor qualidade de vida, e isso elas podem encontrar no ambiente rural. No campo, é possível esquecer estresse urbano, saber a procedência dos alimentos, respirar ar puro e saudável, encontrar sossego e tranqüilidade.

Nesse contexto, o turismo rural surge como forma alternativa de renda: um negócio que permite aos proprietários rurais manter suas propriedades produtivas, verticalizando a produção e gerando empregos para a população local. Alem desses aspectos, as atividades do turismo rural também despertam a consciência ecológica, ao transformar, de modo espontâneo, os produtores em agentes conservadores da natureza, sobretudo à medida que eles percebem o turismo como fonte de renda. O turismo rural corresponde uma forma de lazer saudável, com a consciência ambiental, na qual valores culturais e regionais são resgatados e valorizados. Trata-se de um negócio propício para um país como o Brasil, com grande extensão territorial, diversidade cultural e uns números consideráveis de sítios, chácaras e fazendas, tendo em vista que impulsiona a economia agrícola e estimula o desenvolvimento de regiões.

Os anos 90 para o Distrito Federal são altamente determinantes para a construção de um novo perfil econômico. Até então, o carro-chefe da economia 
local. Era representado apenas pelo serviço público que tanto absorvia periodicamente a mão-de-obra especializada e a falência de inúmeras empresas consideradas tradicionais na capital brasileira.

Os setores produtivos sentem de perto o impacto provocado pela nova ordem econômica, e a buscar por soluções, alternativa aguça e criatividades dos brasilienses, que passam formular um novo cenário para a inserção de seus empreendimentos. Assim, novas oportunidades de negócios começam a ganhar espaço no imaginário de cada cidadão, que procura aliar sua experiência profissional anterior aos recursos materiais disponíveis para a formação e materialização de seus empreendimentos.

\subsection{Vale a Pena}

$\underline{\text { Ver }}$

Palácio da Alvorada pça. dos Três Poderes. Fechado ao público. Residência oficial do presidente da República, o Alvorada é uma construção revestida de mármore e fachada de vidro, sustentada por colunas brancas que se abrem em semicírculos, outro símbolo da genialidade de Oscar Niemeyer. No entanto, a maioria dos presidentes não gostou de morar aqui. Fernando Henrique Cardoso em 1994, foi o primeiro, desde Juscelino, que ficou contente em morar nele. Sarney ficou alguns meses, mas reclamou que o local era um verdadeiro forno, e houve até uma primeira-dama que chamou o Alvorada de "aquário". Collor morou em sua residência, a Casa da Dinda, e Itamar Franco preferiu continuar na residência do vice-presidente, o Palácio do Jaburu.

Catedral metropolitana N. S. Aparecida Eixo Monumental Leste. Tel. (61) 224.4073. Diariam 8h-18h. Esplêndido projeto de Niemeyer. A nave circular é iluminada por luz natural que vaza por vitrais coloridos de Mariane Perrett, que formam as paredes. Para sustentar a estrutura, colunas curvas se abrem e se 
fecham em forma de coroa, encimadas por cruz metálica. No interior da nave, flutuam no ar três anjos de alumínio fundido esculpidos por Alfredo Ceschiatti. Painéis de Di Cavalcanti representam a Via Sacra. À entrada da catedral, "Os Evangelistas", quatro estátuas de bronze de Ceschiatti; ao lado, os sinos do campanário, doados pelo governo espanhol.

Teatro Nacional Eixo Monumental, ao lado da rodoviária. Tel. (61) 325.6107. Diariam 9h-21h. Projeto de Niemeyer tem forma de pirâmide irregular, com composição plástica de cubos e retângulos de Athos Bulcão. Tem três salas de espetáculos, obras e galeria de arte. No prédio anexo da Secretaria da Cultura, na sala Athos Bulcão, deve ser exposto o acervo do Museu de Arte de Brasília.

Palácio do Itamaraty Esplanada dos Ministérios, s/n. Tel. (61) 411.6640. Seg-sex 15h-17h, sáb e dom 10h-14h. Também projetado por Niemeyer, é sede do Ministério das Relações Exteriores. Circundado por espelhos d'água que refletem os arcos da fachada e das laterais. Jardins de Burle Marx, com plantas da Amazônia. No centro dos espelhos d'água, a escultura de Bruno Giorgi "O Meteoro", de mármore de Carrara, parece flutuar.

Palácio da Justiça Esplanada dos Ministérios. Tel. (61) 312.7000. Fechado para reforma. Sede do Ministério da Justiça, projetado por Niemeyer. Jardins e bela fachada de arcos que sustentam lajes curvas de concreto aparente, por onde deslizam cortinas d'água. $O$ povo diz que as cortinas simbolizam um choro permanente porque ele "acha" o palácio em frente, do Itamaraty, muito mais bonito.

Palácio do Buriti Eixo Monumental Oeste. Tel. (61) 316.4111. Seg-sex 8h-18h. Sede do governo do Distrito Federal, projetado por Mauro Jorge Esteves. Nos jardins, as esculturas "A Loba Romana", cópia de "A Loba do Capitólio", doada pela Prefeitura de Roma, e "Forma Espacial no Plano", de Enio Iommi, doada pelo governo argentino. 
Palácio do Jaburu Setor de Hotéis e Turismo Norte. Fechado ao público. É residência oficial do vice-presidente da República. Projeto de Niemeyer, jardins de Burle Marx, com árvores frutíferas e plantas da região. Só pode ser visto de longe.

Memorial JK Eixo Monumental Oeste. Tel. (61) 226.7860. Seg-sex 9h-17h45. Homenagem ao fundador da cidade, tem um pedestal de 28 metros com a estátua de Juscelino. Abriga a biblioteca de JK, com mais de 3 mil volumes, sala de pesquisas, auditório. A câmara mortuária com os restos mortais do ex-presidente é um salão circular com teto decorado por vitrais coloridos de Mariane Perrett.

Espaço Lúcio Costa Sub-solo da pça. dos Três Poderes. Tel. (61) 321.9843. Ter-dom 9h-18h. Homenagem ao autor do plano urbanístico de Brasília. A peça permanente é uma maquete de Brasília de $13 \mathrm{~m}$ × $13 \mathrm{~m}$, de autoria de Antonio José.

Santuário Dom Bosco W3 Sul, Q 702. Tel. (61) 223.6542. Seg-sáb 7h-18h, dom 7h-12h30 e 14h-18h. Projeto de Carlos Alberto Naves. Templo com paredes de arcos góticos de $18 \mathrm{~m}$ de altura, fechados com vitrais em 12 tonalidades de azul, do belga Humberto Vandró, que mudam de nuance de acordo com a posição do sol. Nas portas de bronze há quadros das visões proféticas de D. Bosco. Jardins de Burle Marx.

Ermida de D. Bosco lago Paranoá, acesso pelo Lago Sul e Estr. Parque Dom Bosco. Aberto 24 h. Construída sobre o paralelo 15, local onde D. Bosco previu que surgiria uma nova civilização. Na minúscula capela, em forma de pirâmide, está a imagem do santo padroeiro da capital, esculpida em mármore de Carrara pelos irmãos Arreghini di Pietra Santa. Bela vista dos arredores da cidade.

Museu Histórico de Brasília pça. dos Três Poderes. Tel. (61) 223.7728. Seg-sex 9h-18h; sáb, dom e feriados 10h-18h. Estrutura de concreto armado e mármore, com a cabeça de Juscelino Kubitschek esculpida em pedra-sabão. No interior, inscrições com frases de Oscar Niemeyer e Juscelino sobre a construção de Brasília. 
Museu de Arte de Brasília Setor de Hotéis e Turismo Norte, Lt. 2A. Tel. (61) 325.6242. Fechado p/ reforma. Acervo exposto no anexo do Teatro Nacional. Acervo com mais de 700 obras da arte brasileira dos últimos 30 anos, com telas de Iberê Camargo, Tomie Othake, Athos Bulcão, Siron Franco, João Câmara. A tela "Exposição e Motivos da Violência", de Câmara, venceu o prêmio do Salão de Brasília de 67 com o nome de "AI-5" (o ato institucional que cassou direitos políticos). Em pleno regime militar, a obra desapareceu e só foi encontrada em 91 no porão do museu.

Igrejinha Entrequadra 307/308 Sul. Tel. (61) 242.0149. Seg-sex 9h-17h, sáb 6h17h e dom 7h-19h30. A Igreja N. S. de Fátima é o primeiro templo construído em Brasília. Com painel de azulejos de Athos Bulcão, sua forma lembra uma corneta, nome que se dá àquele chapéu de abas largas usado pelas freiras vicentinas.

Cruzeiro de Brasília Eixo Monumental Oeste. Cruz de madeira situada no ponto mais alto do Plano Piloto, onde foi rezada a primeira missa de Brasília, em 1957. Vista de quase 360 graus da cidade.

Torre de TV Eixo Monumental. Projeto de Lúcio Costa, com 218 metros de altura. É centro de retransmissão das emissoras de rádio e TV, e ponto de referência da cidade. Do mirante, a 75 metros de altura, vista de cartão-postal.

$\underline{\operatorname{Ir}}$

Parque da Cidade Várias entradas, uma delas pelo Eixo Monumental. Tel. (61) 225.2451. Aberto 24 h. São 420 hectares, com urbanismo de Lúcio Costa, arquitetura de Niemeyer e paisagismo de Burle Marx. Há ciclovia, kartódromo, campo de aeromodelismo, estádio hípico, lago com pedalinhos, bosque com churrasqueiras. A atração é a piscina de ondas artificiais. 


\section{Passear}

Catetinho BR-040, km 0. A 27 km da rodoviária. Tel (61) 380.1921. Diariam 8h18h. Primeiro projeto de Niemeyer para a cidade, tombado pelo Patrimônio Histórico Nacional. Construído com madeira para ser a residência do presidente durante a construção de Brasília, conserva móveis e objetos originais.

Vale do Amanhecer Em Planaltina, a $42 \mathrm{~km}$ pela DF-15, km 10. Tel. (61) 389.1258. Diariam 10h-24h. Comunidade mística fundada pela vidente Tia Neiva. Maior exemplo de sincretismo religioso no país, lá se realizam, todos os dias, cerca de cem rituais dos mais variados cultos. Na praça, no centro do povoado, há um lago formado por uma estrela de Davi de concreto armado, onde se realizam as cerimônias, e uma pirâmide para energização. Os adeptos dizem que o templo principal teve arquitetura e decoração orientada por espíritos recebidos por Tia Neiva. Mais de mil médiuns moram no local, que funciona como uma cidade -com escola, creche, fábrica de tijolos, mercearia e outros serviços.

Voar De ultraleve sobre a capital. Ótima chance de ver o Plano Piloto desenhado no solo como um pássaro. Brasília Ultraleve Clube, tel. (61) 224.7035.

Navegar No lago Paranoá. O barco Tôa-Tôa, do Clube ASBAC acomoda até 50 pessoas com todas as mordomias. Sábados, domingos e feriados, o roteiro dura duas horas: sai do ASBAC, no setor de clubes, e passa pela ermida de Dom Bosco, barragem do lago e península do palácio da Alvorada. Infs. e reservas para o barco Tôa-Tôa, tel. (61) 982.1161. 


\section{Comprar}

Artesanato de couro, pedras, cerâmica; flores do cerrado. Em torno da torre de TV, nos fins-de-semana. Outras opções são os shoppings, "Pergunte para a pessoa que está ao seu lado que ela saberá onde tem um shopping", hoje são tantos, que é muito fácil encontrar um...". 
Anexo 


\section{Anexo I}

\section{Como usar uma Bússola?}

Este artigo tem como objetivo o uso da bússola como instrumento de orientação para atividades outdoor esportivas e também para geografia e geologia. Por isso, vamos nos restringir às bússolas geográficas e às bússolas de geólogo.

\section{A Bússola Geográfica}

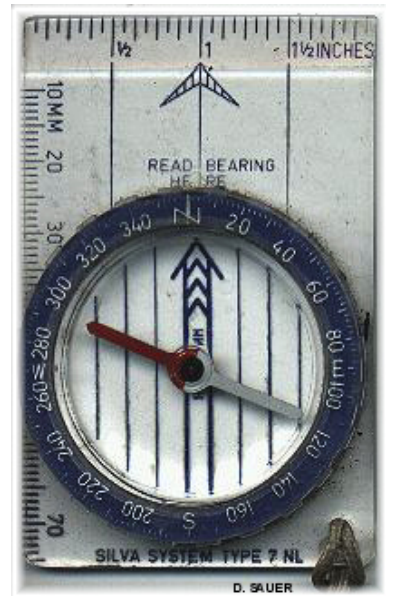

Figura18 - Bússola geográfica

A bússola geográfica é indicada para atividades como caminhadas e ciclismo. Normalmente ela possui uma base em acrílico transparente, que vem com régua e graduações gravadas na base de acrílico. Com isso, fica fácil fazer a orientação da bússola, diretamente no mapa, e calcular distâncias e prolongamento de direções.

Normalmente uma bússola geográfica mede ângulos horizontais, normalmente o Azimute. Algumas possuem também a graduação em quadrantes para medir também o Rumo. 


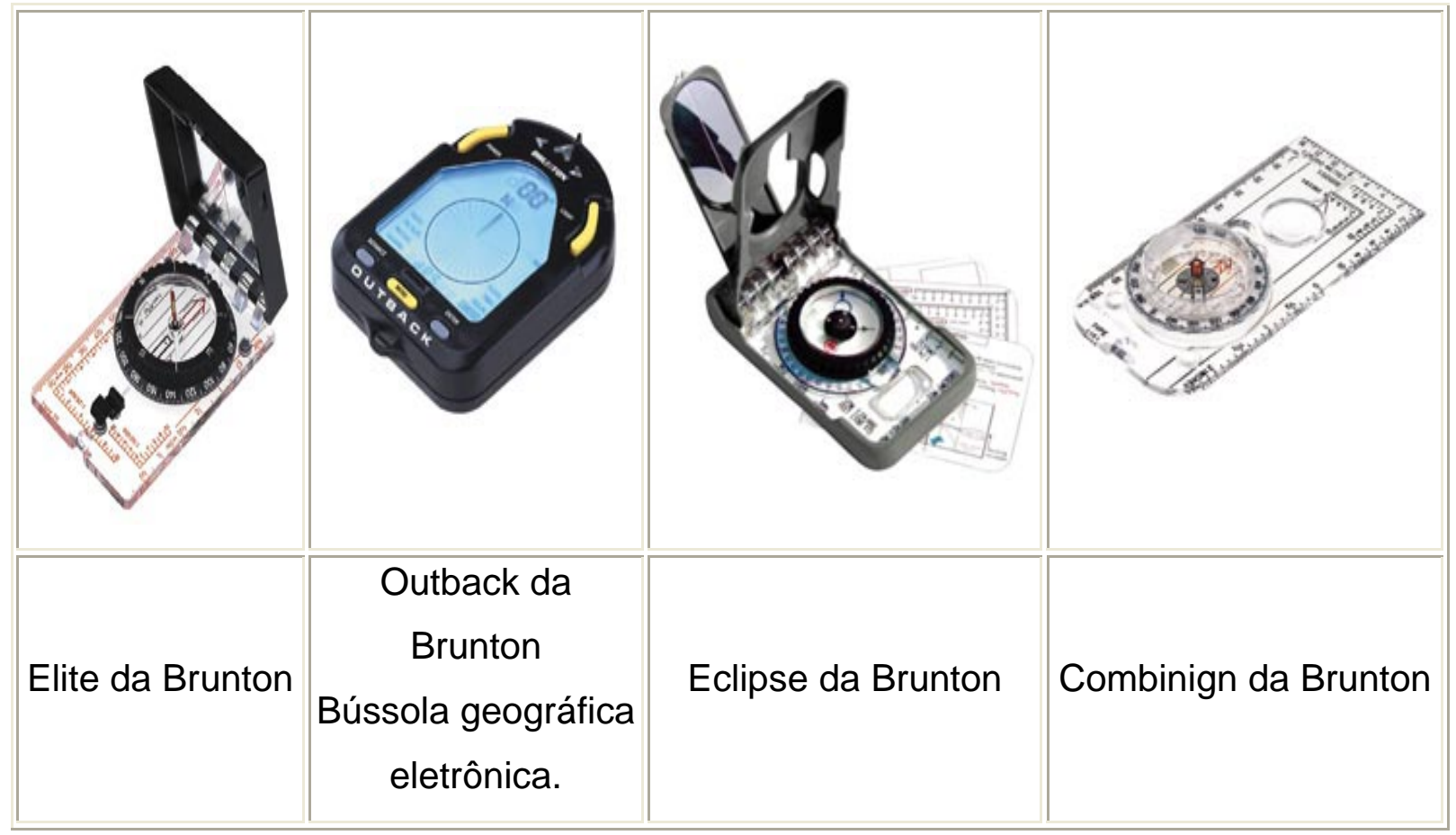

Figura19 - Tipos de Bússolas geográficas

\section{A bússola de Geólogo}

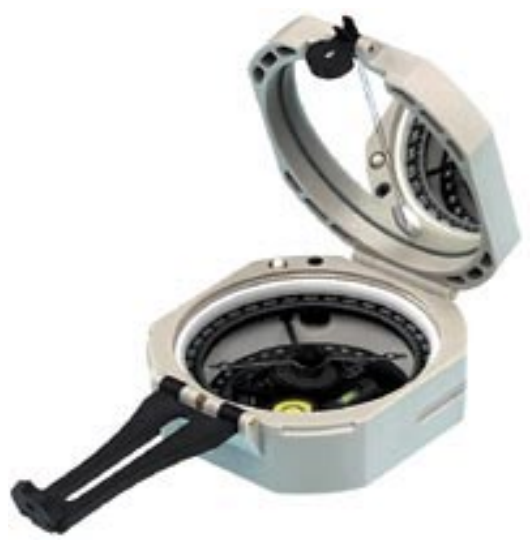

Figura20- Bússola de geólogo

A bússola de Geólogo é um aparelho usado para atividades de campo mais técnicas como: Geologia, Engenharia Civil, Geomorfologia e Espeleologia. 
Ela é a combinação de vários aparelhos: bússola, clinômetro, prumo, nível.

\section{Uma bússola sempre aponta para o Pólo Norte?}

Respostas corretas poderiam ser: Sim! ; Nem sempre! Quase nunca! Depende apenas de qual Norte estamos falando, de que bússola temos, e de onde estamos. Vamos entender?

A bússola eletrônica de um GPS e alguns modelos de bússolas eletrônicas, (se assim configuradas) podem apontar para o Norte, pois elas podem se orientar por uma rede de satélites. Já as bússolas magnéticas (e uma boa parte das eletrônicas), não. Aliás, antes disso, devemos entender que existem mais de um Norte.

Norte Verdadeiro (TN) - Posição geográfica da interseção do eixo de rotação da terra, com a superfície no hemisfério Norte. Este é o Norte Geográfico.

Norte Astronômico (AN) - Aponta para a estrela Polar visível no hemisfério Norte. Tem um desvio de aproximadamente $0.7^{\circ}$ em relação ao Norte Verdadeiro.

Norte Magnético (MN) - Ponto de convergência das linhas do campo magnético da terra. Tem um desvio de $10^{\circ}$ para Leste.

Norte da Bússola (CN) - É a direção da reta tangente à linha do campo magnético da localidade. Complicado? Bem a explicação mais simples, é a seguinte, As linhas de um campo magnético são curvas, como naqueles ímãs dos livros de segundo grau. Mas para piorar, no caso da Terra, elas são tortas, e a agulha da bússola se mantém alinhada com esta linha de campo. Os erros podem variar de 0 até algo perto de $35^{\circ}$, muda com a latitude, longitude, altitude, e com a ocorrência de anomalias magnéticas. (???) Calma, vamos entender isso logo adiante. 


\section{Uma dúvida sobre polaridade}

Se a Física ensina que em magnetismo pólos iguais se repelem, como é que a ponta Norte da agulha aponta para o Pólo Norte? Será que os pólos da terra têm nome trocado, ou são os pólos da agulha que tem os nomes trocados? Nenhum dos dois. Por convenção, foi chamado de Pólo Norte Magnético aquele que ficava perto do Pólo Norte Geográfico. A agulha da bússola é um magneto, e por convenção, leva o nome de Norte a extremidade de um magneto que aponta para o Norte. Tudo claro agora?

\section{Para fins de cartografia e orientação, qual o Norte interessa?}

Sem dúvida, o Norte Verdadeiro, ou seja, o Geográfico. Por convenção, o alinhamento vertical dos mapas aponta sempre para o Norte Verdadeiro.

\section{Declinação Magnética}

Para que uma bússola possa apontar para o Norte Verdadeiro, é necessário fazer uma correção em seu círculo graduado. O valor em graus desta correção, é chamada "Declinação Magnética".

Porquê declinação e não inclinação? Simples, quem criou o termo foram pessoas do hemisfério norte, onde o campo magnético desvia-se Oeste, e por isso deve-se subtrair-se do Azimute alguns graus para fazer a correção. Por isso eles declinam a medida. Nós aqui acrescentamos alguns graus ao Azimute, mas (sempre querendo concordar com os primos do Norte), usamos o mesmo termo "declinar".

Fazendo uma consulta para a região de Brasília, para o ano de 2001, a resposta é a seguinte: 
Ah! Lembre-se que se sua latitude é Sul, então ela deve ser informada em valores negativos $\left(-16^{\circ} \mathrm{S}\right)$.

Veja que os dados de declinação magnética das cartas mais antigas podem usar um modelo ultrapassado, e o pressuposto de evolução constante da declinação pode não ter se mantido. 


\section{Anexo II}

\section{Noções sobre GPS}

O Sistema GPS (Sistema de Posicionamento Geográfico) destina-se a basicamente oferecer ao usuário sua posição geográfica expressa em coordenadas geográficas. O sistema consiste de uma rede de satélites dispostos em órbitas diversas, de modo que em qualquer ponto do planeta, sempre deveria haver uma quantidade razoável de satélites (3ou mais) em movimento sobre o céu do usuário.

A outra ponta do sistema, é o receptor de sinais GPS que o usuário deverá portar. Este receptor vai receber o sinal dos satélites "visíveis" e vai calcular a sua posição. Para isso, o receptor (que na verdade é um computador dedicado a esta tarefa), possui um Almanaque de órbita dos satélites do sistema, que informa a identificação dos satélites, e parâmetros de suas órbitas. Os satélites possuem um relógio interno de alta precisão cujo horário é sincronizado entre eles.

De tempos em tempos (a cada 30 segundos, se não me engano), eles transmitem sua identificação e a sua hora. O sinal dos satélites mais próximos (mais em cima do usuário), vão chegar primeiro, os mais distantes (próximos ao horizonte) vão demorar um pouquinho mais. A diferença de tempo que existe entre a recepção da hora transmitida pelos satélites é usada para calcular a posição relativa do usuário em relação aos satélites. Daí calcula-se em que posição o receptor está na superfície da terra, com base nos parâmetros das órbitas.

Quando ligamos o GPS, ele executa um auto teste e em seguida, começa a rastrear os satélites, e elegendo aqueles que tem o sinal mais forte para orientarse. Durante este processo ele avisa que está procurando por satélites. Quando enfim, ele localiza os satélites, e calcula a posição atual, ele mostra um aviso dizendo que está pronto para navegação. Além disso, ele informa se pode ou não fornecer, além da posição (latitude / longitude), a altitude "Pronto para navegação 3D (3 dimensões)". Esta depende de ele conseguir encontrar pelo menos 3 
satélites com bom nível de sinal. Se forem apenas dois, ele vai dizer que "está pronto para navegação 2D (Duas dimensões)".

Além disso, ele informa a precisão da estimativa da posição. Esta precisão depende da quantidade de satélites e da intensidade do sinal recebido deles. Normalmente é algo entre 30 metros (piores casos) até 3 metros (para recepções excepcionais). Apesar do sistema GPS ter sido projetado para obter precisão maior, os aparelhos para uso civil pessoal trabalham com estes limites de precisão.

Hoje em dia, existem diversos fabricantes de receptores GPS e cada um deles possui inúmeros modelos oferecendo diferentes recursos. Existem GPSs simples, destinados a aventura, recreação. GPSs para off-road, navegação marítima, navegação aeronáutica, e topografia de precisão.

\section{Sistemas Alternativos}

O Sistema GPS é americano, controlado pela Força Aérea Americana. Tem a flexibilidade de permitir ser desligado em uma localidade, ou ter a sua precisão alterada seletivamente.

A União Soviética desenvolveu seu próprio sistema, o GLONASS. O Europa está preste a lançar o dela, assim como a China. Com isso, podemos perceber a importância estratégica e econômica de se ter um sistema de posicionamento global confiável.

Até maio/1999, os EUA colocavam um ruído intencional na transmissão do sistema GPS que reduzia para 50metros a precisão da posição acusada por GPSs que não fossem os dos militares americanos. Nesta época, para navegar com maior precisão, era necessário apelar para os GPSs Poloneses que usavam a rede GLONASS. 


\section{Considerações sobre a disseminação do uso dos GPSs}

Ao longo dos anos, o uso destes aparelhos está se massificando, e acrescentando uma nova dimensão às informações coletadas. Até os dias de hoje, a informação era amarrada a duas dimensões (assunto, tempo [data/hora]). Ultimamente a informação começa a ser circunstanciada a três dimensões (assunto, tempo, local). Veja que as informações traziam como parte de sua descrição, a localização, mas era de pouca utilidade. Às vezes, a localização era inconsistente.

Exemplo: Imagine como informação um relato de um acidente de carro, a ser incluído em um banco de dados policial.

Assunto: Acidente automobilístico

Tempo: 16/04/2002 18:20h

Local: (Aí seria possível que a localização seguisse uma destas formas)

Semáforo do Shopping Pátio Brasil

Semáforo do Hotel das Américas

Setor Comercial Sul, Av. W3, Cruzamento com a Av N1, direção Norte/Sul.

CEP: 70001-006

W3 Sul, em frente ao Banco Citybank.

Semáforo Nº00987

Informação: Texto descritivo do acidente.

Agora, que você tem um banco com centenas ou milhares de ocorrências de acidentes na cidade, e você quer extrair pelo computador uma estatística sobre a taxa mensal de acidentes de carro neste cruzamento. Qual descrição de endereço você forneceria? Será que conseguiria filtrar a totalidade de acidentes com base no endereço escolhido por você? Claro que não! 
Mas, a partir do momento em que seja possível determinar com facilidade as coordenadas, a localização passa a ser uma dimensão da informação, e não parte da descrição dela. Daí, uns montes de informações podem ser circunstanciados pela sua localização: Censo demográfico (principalmente rural), localização de agressões ambientais, atrativos de ecoturismo, foco de enfermidade, ponto de poluição, obstruções à navegação fluvial, etc...

As utilidades são tantas que já existe um projeto para modernizar e expandir o sistema atual de GPS.

As extensões em funcionalidades são inacreditáveis. Mas vamos ficar com o que temos hoje.

\section{Como usar um receptor GPS}

Este aparelho é o mais simples de uma linha de GPSs criados pela Garmin para aventureiros, viajantes, ou pessoas que executem trabalhos como coleta de dados onde a precisão oferecida por ele seja aceitável.

Depois que aprende a usar um, os outros são muito semelhantes.

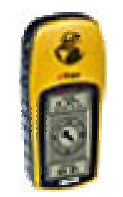

ETrex

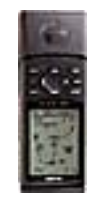

GPS12

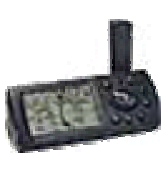

GPS III+

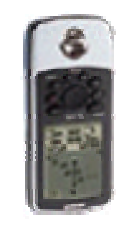

GPS 76

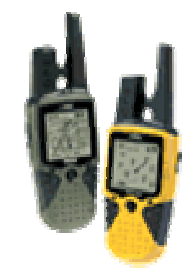

Rino

Figura21- Tipos de GPS 
Apêndice

Cartografia do DF e entorno

\section{Mapa Ecoturístico do Brasil Central}

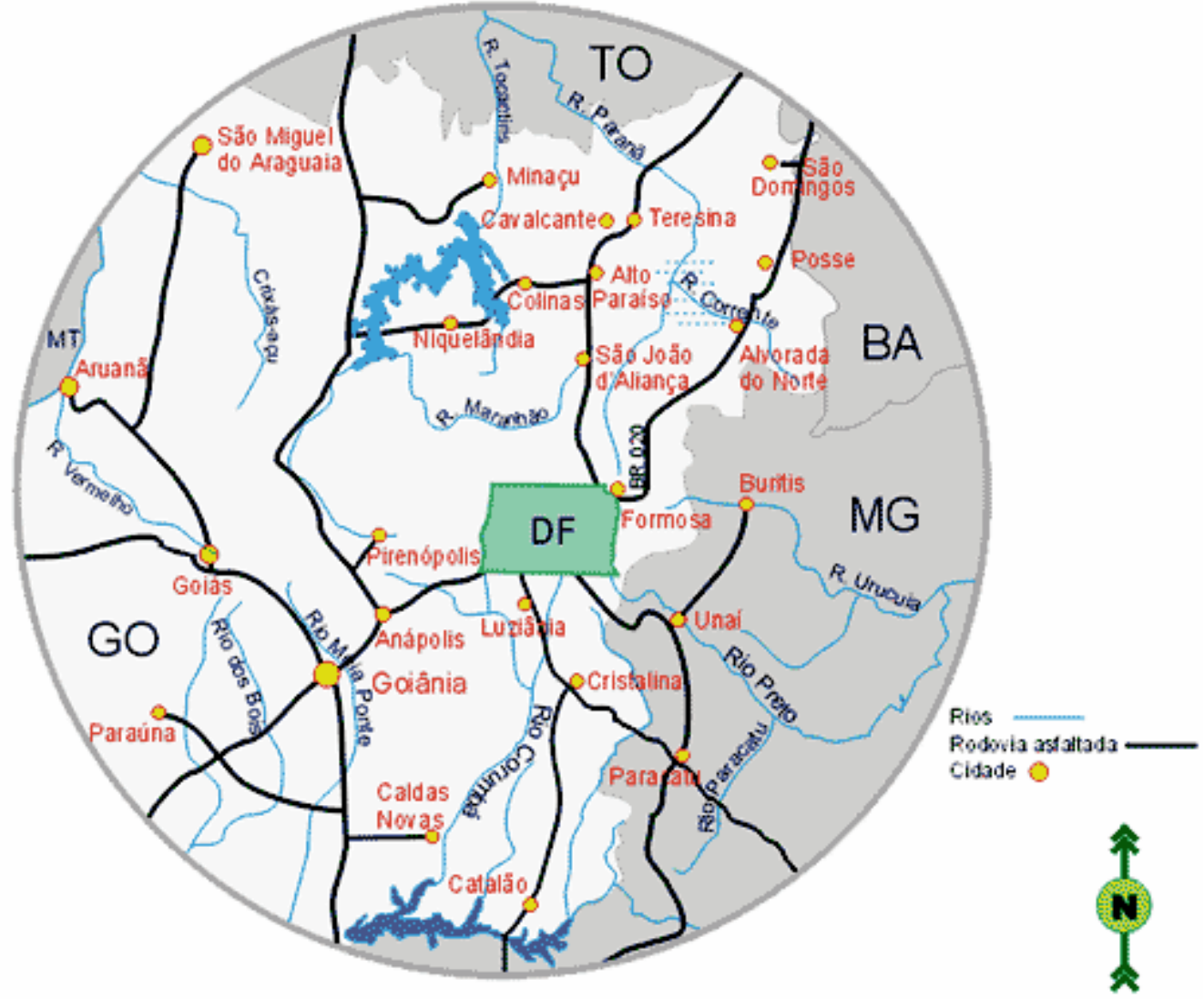

Fonte: Site - www.ecoviagem.com.br 


\section{Cartografia do Tororó}

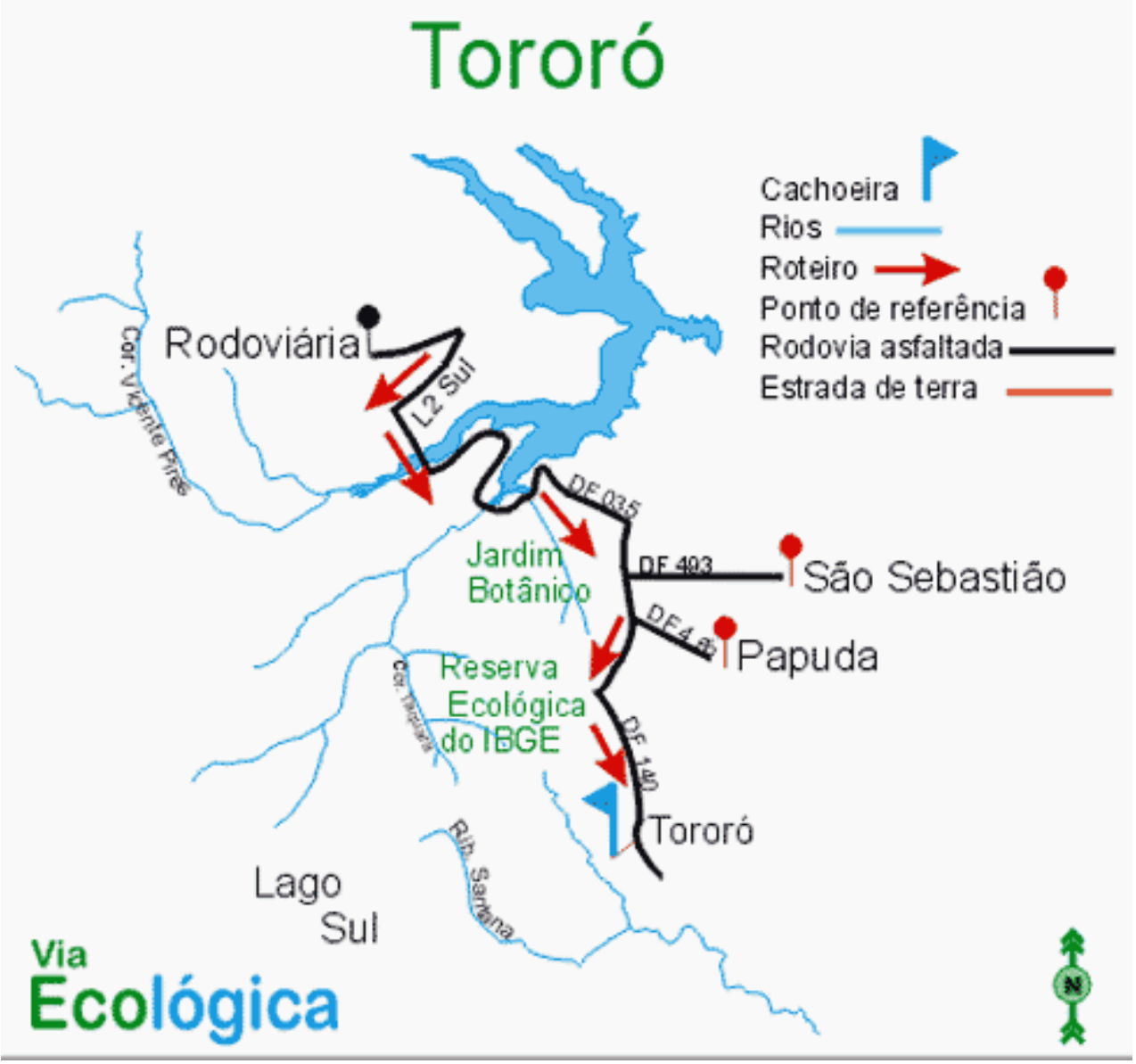

Fonte: Site - www.ecoviagem.com.br 


\section{Cachoeira do Colorado}

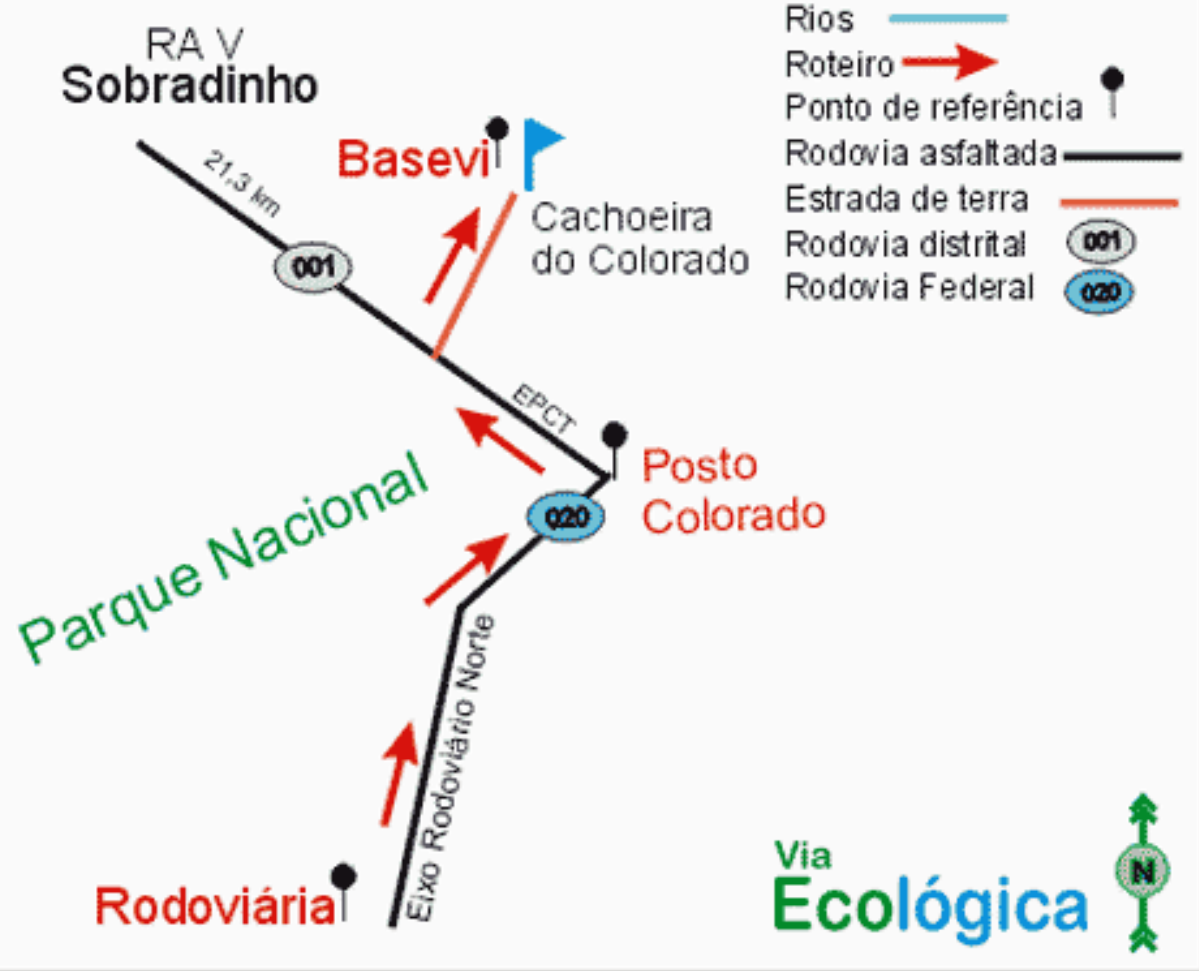

Fonte: Site - www.ecoviagem.com.br 
Cartografia do Poço Azul

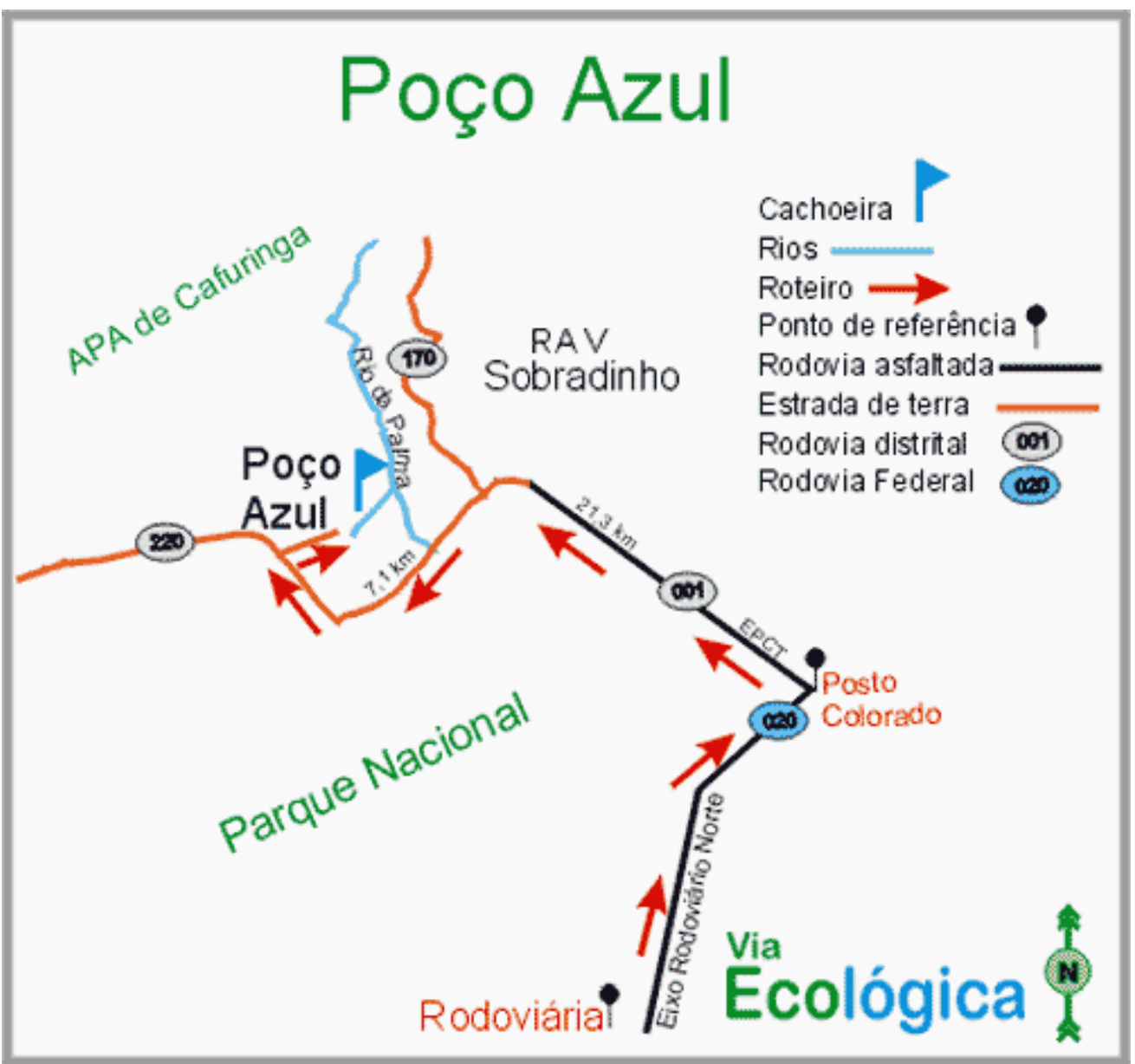

Fonte: Site - www.ecoviagem.com.br 


\section{Bibliografia}

ALMEIDA, J.A.; BLOS, W. O marketing do turismo rural e o desenvolvimento sustentável. In: UFSM (ed.). Turismo rural e desenvolvimento sustentável. Santa Maria: UFSM, 1998. Cap. 1, p.57-64.

AMATO, J. N. Redes de cooperação produtiva e clusters regionais. São Paulo: Atlas, 2000. $163 \mathrm{p}$.

BENI, M. C. Mesa redonda: gestão de turismo no Brasil. Revista de Administração, São Paulo, v. 33, n. 4, p. 5-25, out./dez., 1998.

BROHMAN, J. New directions in tourism for third world development. Annals of tourism research. Great Britain, v. 23, n. 1, p. 48-70, 1996.

CAVACO, C. Turismo rural e desenvolvimento local. In: Rodrigues, B. A A. Turismo e geografia. São Paulo: Hucitec, 2001. p.94-121.

COLTMAN, M. M. Tourism marketing. Princeton: Van Nostrand Reinhold, 1989. p. ?

CORNER, D. M. R. Introdução ao turismo. São Paulo: Roca, 2001. 371 p.

EMBRATUR. Consultado na INTERNET, em 15 de setembro de 2002. www.embratur.gov.br

FRANZEN, Ronaldo. Escalada em Rocha. Apostila Marumby Montanhismo, Curitiba, 1998, $58 \mathrm{p}$.

GIANESE, I. G. N.; CORRÊA, H. L. Administração estratégica de serviços. São Paulo: Atlas, 1994. 233 p.

HOFFMAN. K.; KAPLINSKY, R. The point of transition - from machinofacture to systemofacture. In: . Driving force: the global restructure of technology, 
labour, and investment in the automobile and components industries. London: Westview, 1988. p. 31-71.

INSTITUTO BRASILEIRO DE TURISMO - EMBRATUR. Manual do turismo rural. Brasília: Ministério da Indústria, do Comércio e do Turismo, 1994. 56 p.

IKEDA, A A. Mesa redonda: gestão de turismo no Brasil. Revista de administração, São Paulo, v. 33, n. 4, p. 5-25, out/dez. 1998.

LICKORISH, L. J. e JENKINS, C. L. Introdução ao Turismo. Rio de Janeiro: Campus, p. pp.20-48. 2000. . Política e estratégia de desenvolvimento regional - planejamento integrado e sustentável do turismo. In: LAGE, B. H. G. e MILONE P.C. Turismo. São Paulo: Atlas, 2000. p.165-170.

MARINO, J. E. N. Mesa redonda: gestão de turismo no Brasil. Revista de Administração, São Paulo, v. 33, n. 4, p. 5-25, out/dez. 1998.

MOTA, K.C.N. Marketing turístico: promovendo uma atividade turística. São Paulo: Atlas, 2001.

MOURÃO, Roberto. Novas Formas de Turismo. Consultado na INTERNET, em 18 de setembro de 2002. www.mre.gov.br/rebrasil

OLIVEIRA, L. H. Turismo rural como estratégia para o desenvolvimento do interior do Brasil. São Paulo: Escola de Administração de Empresas - FGV, 1997. p. ?.

PAIXÃO, R. Revista Veja, São Paulo, n. 37, set. 1999.

REJOWSKI, M. Pesquisa turística no Brasil da óptica dos pesquisadores. In: LAGE, B. H. G. e MILONE P.C. Turismo. São Paulo: Atlas, 2000. 281- 297 p. 
SILVA, G. da J.; VILARINHO, C.; DALE, P. J. Turismo em áreas rurais: suas possibilidades e limitações no Brasil. In: UFSM. Turismo rural e desenvolvimento sustentável. Santa Maria: UNIVERSIDADE FEDERAL DE SANTA MARIA, 1998. cap.1, p.11-49.

TÉBOUL, J. A era dos serviços. Rio de Janeiro: Qualitymark, 1999. 295 p.

URRY, J. O olhar do turista. São Paulo: Studio Nobel, 1999. 231p.

UVINHA, Ricardo Ricci. Juventude, Lazer e Esportes Radicais. São Paulo: Manole, 2001, 1. ed. 108p.

WOMACK,J. P.; JONES, D. T.; ROOTS. D. As origens da produção enxuta. A máquina que mudou o mundo. Rio de janeiro: Campus, 1992. p. 7-62.

ZIMMERMANN, A. Turismo rural: um modelo brasileiro. Florianópolis: Autor, 1996. 67p.Artigo

\section{Sites pesquisados}

Http://www.df.sebrae.com.br/preview/creator2/webs/sebrae/Desen_Setorial/turism o_detalhe.cfm http://www.embratur.gov.br/destinos/df/estado.asp?uf=DF http://www.ecoviagem.com.br http://www.azimute.com.br/index2/cursos/curso\%20turismo.htm http://www.eco.tur.br http://www.gpsglobal.com.br 


\section{Glossário}

1. Bote - existem três bons fabricantes nacionais: Zefir, Arboat e Flexboat. A grande diferença está nos tecidos utilizados. (os importados são de Haypalon, e os nacionais, de PVC).

2. Bússola - Agulha magnética móvel em torno de um eixo que passa pelo seu centro de gravidade, montada, geralmente, em caixa com limbo graduado, e usada para orientação.

3. Capacete - É importante que os capacetes sejam ajustáveis para cada cabeça, tenham proteção para as orelhas, furos para permitir fluxo de água e fita de fixação.

4. Cartografia - Arte ou ciência de compor cartas geográficas. Tratados sobre mapas.

5. Cerrado - Conhecido como o mais antigo dos ecossistemas brasileiros, e se caracteriza por uma vegetação tipo savana tropical.

6. Colete - com classe de flutuação Os praticantes consideram os coletes aprovados pela marinha americana os melhores. O colete com maior flutuação é para rios de classe 5 , sendo o mais seguro de todos. Os nacionais estão melhorando bastante, mas apresentam alguns problemas, como por exemplo, descosturar e embolorar com mais facilidade.

7. Computador de Bordo - Auxilia na obtenção de diversos dados como quilometragem e velocidade média, pois indica, basicamente, à distância percorrida pelo veículo.

8. Depredação ambiental - Ato de depredar, saquear, espoliar, roubar, devastar.

9. Destruição ambiental - Destruir o meio ambiente.

10.GPS (Global Pointing Sistem) - Através de informações fornecidas por satélites, indica a posição exata onde o veículo se encontra, além de registrar sua velocidade média, distância entre pontos, etc.

11. Homogeneização - Ato de homogeneizar. Homogeneizar tornar homogêneo que tem suas partes componentes da mesma natureza, solidamente ligadas. 
12. Indoor - Corrida contra o cronômetro praticado numa pista artificial, lamacento e cheia de obstáculos.

13. Mapas - Ajudam na localização e, através da indicação de altitudes, permitem identificar o tipo de relevo a ser percorrido.

14. Navegador - é essencial para a prática segura e bem sucedida do off-road. É ele quem orienta o piloto sobre o percurso, suas dificuldades, a velocidade média a ser mantida, etc. Para isso, conta com o auxílio de diversos instrumentos de navegação.

15. Obstáculos - Embaraço, impedimento, estorvo, barreira.Cada umas das diferentes barreiras que se dispõe numa pista de corrida tornar.

16. Planilhas - De grande importância nas provas de regularidade, descreve 0 trajeto minuciosamente, indicando quilometragens e avisos relevantes.

17. Radicalidade - Torna-se radical, assumir atitudes radicais, tomar o rumo do radicalismo.

18. Raid ou Rally de Velocidade - O veículo deve percorrer o trajeto aproximando-se ao máximo da velocidade e do tempo médios prédeterminados para cada trecho. Para isso, conta com o auxílio indispensável do navegador, que interpreta as informações obtidas por diversos instrumentos que citaremos adiante.

19. Rally Cross Country - É caracterizado pela dificuldade dos obstáculos do percurso, que deve ser transposto no menor tempo possível.

20. Rally de Turismo - É como um cross country menos radical, ou seja, o que vale é a velocidade, mas num caminho bem menos acidentado.

21. Remo - Os remos com cabo em $\mathrm{T}$ proporcionam uma posição mais confortável para remar.

22. Remos individuais - Cada pessoa do bote possui um remo e todos remam juntos. É a modalidade mais praticada no Brasil. Oar Boat Apenas uma pessoa controla um par de remos longos que fica preso em uma estrutura de alumínio sobre o bote.

23. Sustentabilidade - é uma relação entre sistemas econômicos dinâmicos e sistemas ecológicos maiores. Também dinâmicos. Uma relação na qual os efeitos das atividades humanas permanecem dentro dos limites que não deterioram a saúde e a integridade de sistemas auto-organizados que fornecem o contexto ambiental para estas atividades. 
24. Turismo - Soma de relações e de serviços resultantes de um câmbio de residência temporário.

25. Trekking - Na tradução para o português, a palavra trekking quer dizer caminhar, trilhar, andar. 
Universidade de Brasília Centro de Excelência em Turismo

\section{Roteiros Turísticos de Aventura no DF e entorno}

Nome do Aluno: Wlisses Fernando do Santos

Nome do Orientador: Rafael Sanzio Araújo do Santos

Monografia apresentada ao Centro de Excelência em Turismo da Universidade de Brasília como requisito parcial para a obtenção do certificado de Especialização para professores e pesquisadores em Turismo e Hospitalidade.

Brasília, DF, Fevereiro de 2004. 